\title{
一の目潟と黒瀬のマントルカンラン岩捕獲岩の $\mathrm{Rb}-\mathrm{Sr}$ 鉱物アイソクロン年代
}

\author{
$\mathrm{Rb}-\mathrm{Sr}$ mineral isochron ages of mantle peridotite xenoliths \\ from Ichinomegata and Kurose, Japan

$\begin{array}{llll}\text { 阿 } & \text { 部 } & \text { 志 } & \text { 保 (Shiho ABE) }{ }^{*} \\ \text { 山 } & \text { 元 } & \text { 正 } & \text { 継 (Masatsugu YAmAmoro) }{ }^{*}\end{array}$

Petrology, geochemistry and $\mathrm{Rb}-\mathrm{Sr}$ chronology of seven spinel lherzolite-harzburgite xenolith samples from Ichinomegata, northeast Japan and Kurose, southwest Japan were studied. Whole rocks and the constituent minerals were analyzed for $\mathrm{Rb}$ and $\mathrm{Sr}$ contents and ${ }^{87} \mathrm{Sr} /{ }^{86} \mathrm{Sr}$ ratios. The pure minerals were obtained by hand-picking and repetitive washing with hot acids $(2 \mathrm{M} \mathrm{HCl}$, $5 \% \mathrm{HF}$ ) and distilled water.

The peridotite xenoliths from Ichinomegata show wide variations in mineral and chemical compositions; clinopyroxene contents range from 4 to 13 volume\%, $\mathrm{Cr} /(\mathrm{Cr}+\mathrm{Al})$ ratios of spinel range from 0.19 to 0.41 and $\mathrm{MgO}$ contents of whole rock range from 38 to 46 weight\%. The chondrite-normalized patterns of whole rock vary from LREE-depleted to flat or U-shaped. In spite of above petrographical and geochemical variations, ${ }^{87} \mathrm{Sr} /{ }^{86} \mathrm{Sr}$ ratios of the clinopyroxenes are very uniform $(0.7033 \sim 0.7034)$. Rb-Sr mineral isochron ages of $208.9 \pm 80.1 \mathrm{Ma}, 233.8 \pm 8.4 \mathrm{Ma}$, $252.9 \pm 19.8 \mathrm{Ma}$ and $310.8 \pm 23.3 \mathrm{Ma}$ are given by olivine, orthopyroxene, clinopyroxene and whole rock from each of four peridotite xenoliths. Since the peridotites have the relatively narrow range of ages and wide range of equilibrium temperatures, it is believed that a large-scale isotopic equilibration has occurred at various depths in the upper mantle beneath Ichinomegata.

The peridotite xenoliths from Kurose show narrow ranges in mineral and chemical compositions; clinopyroxene contents range from 7 to $9 \mathrm{vol} . \%, \mathrm{Cr} /(\mathrm{Cr}+\mathrm{Al})$ ratios of spinel range from 0.28 to 0.31 and $\mathrm{MgO}$ contents of whole rock range from 41 to $43 \mathrm{wt} . \%$. On the other hand, ${ }^{87} \mathrm{Sr} /$ ${ }^{86} \mathrm{Sr}$ ratios of the clinopyroxenes are very diverse $(0.7034,0.7039$ and 0.7043$)$, compared with those in Ichinomegata peridotites. The mineral isochrons based on the data of pyroxenes and whole rock also show very variable ages and initial ${ }^{87} \mathrm{Sr} /{ }^{86} \mathrm{Sr}$ ratios. The $\mathrm{Rb}-\mathrm{Sr}$ mineral isochron ages of $129.9 \pm 4.8 \mathrm{Ma}, 312.8 \pm 16.7 \mathrm{Ma}$ and $487.2 \pm 9.1 \mathrm{Ma}$ indicate large intervals between the equilibration events.

Keywords : $\mathrm{Rb}-\mathrm{Sr}$ mineral isochron, Mantle peridotite xenolith, Ichinomegata, Kurose, Japan

\section{I. はじめに}

日本列島に産する深部起源の岩石については，これ までに博多湾北方の黑瀬に産する下部地凯起源の苦鉄 質グラニュライト捕獲岩や北海道の幌満カンラン岩体 からアイソクロン年代が報告され，それぞれ年代の示
す意味が検討されている (Yoshikawa et al., 1993 ; 芳 川・中村，1994；加々美ら，1999)。カンラン岩捕獲岩 の同位体的研究としては，秋田県男鹿半島の一の目潟 や島根県隠岐島後の試料について, Zashu et al. (1980), Nohda and Wasserburg (1986), Kagami et al. (1986), Menzies and Hawkesworth (1987) およ

(平成 11 年 4 月 9 日受付，平成 11 年 7 月 22 日受理)

* 秋田大学工学資源学部応用地球科学教室, $\overline{\mathrm{T}}$ 010-8502 秋田市手形学園町 1-1

* Institute of Applied Earthsciences, Faculty of Engineering and Resource Science, Akita University, Akita 010-8502, Japan

* E-mail : abe_shiho@galena.mine.akita-u.ac.jp, yama@ipc.akita-u.ac.jp 


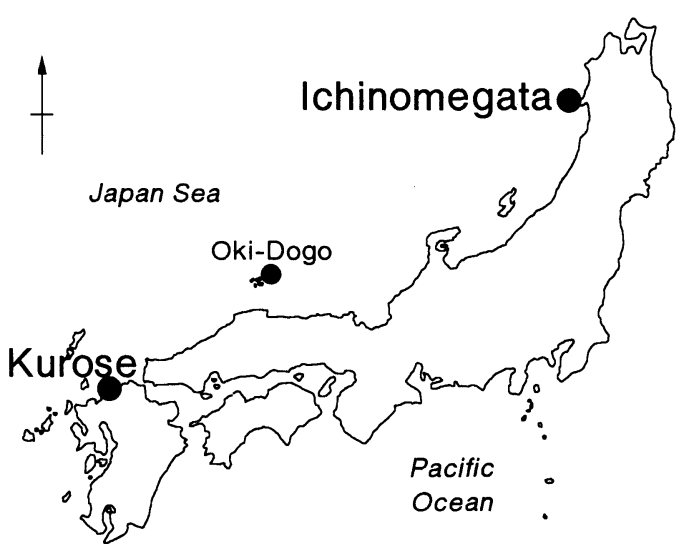

Fig. 1. Locality map of Ichinomegata maar, northeast Japan and Kurose reef, southwest Japan.

び Porcelli et al. (1992) の報告がある。しかし, い ずれも全岩や単斜輝石の同位体比が分析されているの みで，アイソクロン年代は得られていない。

本論文では, 一の目潟と黒瀬に産するカンラン岩捕 獲岩の岩石学的・地球化学的な特徴を述べるとともに, 構成鉱物の $\mathrm{Sr}$ 同位体比と $\mathrm{Rb}$ および $\mathrm{Sr}$ の定量分析值 から鉱物アイソクロン年代を報告し，その意味を検討 する。また捕獲岩から示される両地域のリソスフェア マントルの同位体的特徵についても述べる。

\section{II. 分 析試料}

一の目潟は秋田県男鹿半島の西端に位置する目潟火 山を構成する単成火山のひとつである (Fig. 1)。黒瀬 は博多湾北方に位置する玄武岩からなる岩礁である。 本研究では, 両地域に産する超苦鉄質捕獲岩のうちレ ルゾライトとハルツバージャイトを対象とした。試料 は, 一の目潟の第 I.II 期の泥流堆積物 (Katsui et al., 1979), および黒瀬を構成するアルカリ玄武岩質溶岩 (Ishibashi, 1970) から採集した。前者の試料について は, 周囲を薄くとりまく安山岩質軽石をカッターやグ ラインダで取り除いた。後者の場合は, 露頭から捕獲 岩の周縁部を除く内側の部分だけを採集した。1個の 試料から薄片製作, 全岩分析および鉱物分離を行うた め, 分析には径 $5 \mathrm{~cm}$ 以上のものを使用した。

\section{III. 岩石記載}

\section{1. 肉眼的特徵}

本研究では,一の目潟のカンラン岩について 5 試料, 黒瀬のカンラン岩について 3 試料を用いた。カンラン
岩はいずれも露頭で亜円碟状を呈するが, 一の目潟の 試料のなかには, 節理面に囲まれたような多面体から なるものもある。両地域の試料の構成鉱物はほぼ均等 に分布していることが多いが, 一部の黒瀬の試料には 単斜輝石の濃集部がみられる。一般にもろいので軽く 砕くだけで鉱物粒子に分離できる。分離した構成鉱物 の粒径をみると, 一の目潟のカンラン岩は比較的よく そろっている。しかし, 黒瀬のカンラン岩は後述のよ うにポーフィロクラスティック組織 (Mercier and Nicolas, 1975）を示すため，様々な粒径の結晶からな る。鉱物はいずれも新鮮で特徴的な色を示すので, 双 眼実体顕微鏡を使用してのハンドピックは容易であ る。

\section{2. 組織およびモード組成}

一の目潟のレルゾライトとハルツバージャイトは, プロトグラニュラー組織 (Mercier and Nicolas, 1975) のほかプロトグラニュラーとモザイク等粒状の漸移組 織を示す。モード組成は変化が大きく, 全岩の主成分 の変化幅の原因になっている。カンラン石のモードは 48 volume (vol.)\%から 77 vol.\%まで変化する (Table 1)。粒径は 1 $2 \mathrm{~mm}$ 程度で, しばしばキンク バンドが発達している。まれに包有物として斜方輝石 やスピネルを含む。斜方輝石は 18～29 vol.\%まで変化 する。粒径は最大 $4 \mathrm{~mm}$ に達するものもあるが, 普通 $1 \mathrm{~mm}$ 程度である。まれに包有物としてカンラン石や スピネルを含む。単斜輝石は 4 13 vol.\%まで大きく 変化する。粒径は普通 $1 \mathrm{~mm}$ 以下であるが, 試料番号 $\mathrm{N}-8$ は $2 \mathrm{~mm}$ 以上のものを含む。スピネルは $0.8 \sim 3.0$ vol.\% \%で変化する。鉱物の粒間に存在するほか, 粒径 $0.5 \mathrm{~mm}$ 以下の粒状の結晶として包有される場合もあ る。さらに, 斜方輝石や単斜輝石の核部に離溶ラメラ あるいは微細な包有物 (粒径 $0.1 \mathrm{~mm}$ 以下) としても存 在する。角閃石はオープンニコルで黄褐色を呈し, し ばしば単斜輝石を置換している。 $\mathrm{N}-8$ は幅 $3 \mathrm{~mm}$ 程度 の角閃石脈を含むが，この脈を除いても角閃石のモー ド量は 5 試料の中で最も多い (3 vol. \%, Table 1)。

黒瀬のレルゾライトはポーフィロクラスティック組 織を示す。カンラン石のモードは 55～67 vol.\%まで変 化する。ポーフィロクラストは粒径 $1.5 \mathrm{~mm}$ 程度でキ ンクバンドが発達している。ネオブラストは粒径 1 $\mathrm{mm}$ 以下が普通である。斜方輝石は 23～36 vol.\%まで 変化する。ポーフィロクラストは粒径 $1 \sim 1.5 \mathrm{~mm}$ 程度 で,カンラン石と同様にキンクバンドが発達している。 ネオブラストは粒径 $0.5 \mathrm{~mm}$ 以下が普通である。単斜 輝石は 7〜9 vol.\%まで変化する。粒径は普通 $0.5 \mathrm{~mm}$ 
Table 1. Textures, modal compositions (volume $\%$ ) and equilibration temperatures of the peridotite xenoliths from Ichinomegata and Kurose

\begin{tabular}{|c|c|c|c|c|c|c|c|c|c|c|}
\hline No. & $\begin{array}{l}\text { Rock } \\
\text { Type } \\
\end{array}$ & Texture & olv & opx & cpx & sp & amph & symp & others & $\mathrm{T}\left({ }^{\circ} \mathrm{C}\right)^{* *}$ \\
\hline \multicolumn{11}{|c|}{ Ichinomegata } \\
\hline $\mathrm{N}-8$ & sp lh & $\begin{array}{l}\text { proto } \\
\text { - equi }\end{array}$ & 47.7 & 29.2 & 12.9 & 2.8 & $3.0^{*}$ & 3.9 & 0.5 & 872 \\
\hline $370-1$ & sp lh & proto & 60.9 & 23.7 & 12.2 & 2.5 & 0.2 & 0 & 0.5 & 887 \\
\hline $\mathrm{L}-52$ & $\mathrm{sp} \mathrm{lh}$ & proto & 73.8 & 17.5 & 5.5 & 3.0 & 0 & 0 & 0.1 & 968 \\
\hline 961 & sp hz & proto & 76.6 & 17.5 & 3.7 & 0.8 & 1.2 & 0 & 0.3 & 967 \\
\hline 962 & $\mathrm{sp} \mathrm{lh}$ & proto & 64.1 & 27.5 & 5.2 & 1.4 & 1.7 & 0 & $\operatorname{tr}$ & 881 \\
\hline \multicolumn{11}{|c|}{ Kurose } \\
\hline $\mathrm{K}-1$ & sp lh & porphy & 65.3 & 24.5 & 8.0 & 2.1 & 0 & 0 & 0.1 & 904 \\
\hline $\mathrm{K}-4$ & $\mathrm{sp} \mathrm{lh}$ & porphy & 66.5 & 22.5 & 8.8 & 1.8 & 0 & 0 & 0.4 & 1003 \\
\hline $\mathrm{K}-6$ & $\mathrm{sp} \mathrm{lh}$ & porphy & 55.0 & 36.1 & 7.3 & 1.6 & 0 & 0 & 0.7 & 929 \\
\hline
\end{tabular}

*, except an amphibole vein; ${ }^{* *}$, estimated by a pyroxene geothermometer of Wells (1977).

lh, lherzolite; hz, harzburgite ; proto, protogranular texture; equi, equigranular texture ; porphy, porphyroclastic texture; olv, olivine; opx, orthopyroxene; cpx, clinopyroxene ; sp, spinel ; amph, amphibole; symp, symplectite (finegrained mineral aggregate) ; tr, trace.

程度である。スピネルは 1.6〜2.1 vol.\%まで変化する。 鉱物の粒間にヒイラギの葉状に存在するほか包有物と しても存在する。 3 試料とも, スピネルと斜方輝石の粒 界に，主に微細なカンラン石（粒径 $0.03 \mathrm{~mm}$ 以下）か らなる鉱物集合体が観察される。この組織は, Ionov et al. (1995) がバイカル湖南方に産するカンラン岩捕獲 岩で観察した組織に類似している。彼らは, スピネル と斜方輝石の粒界に形成された微細なカンラン石とア ルカリに富む斜長石の集合体を交代流体の産物である と説明した。黑瀬の試料の場合にはアルカリに富む鉱 物の有無が確認できないので, その組織が交代作用に よるものかぞうかは判断できない。ただし，それらの カンラン石が流体包有物に富むことは注目される。

\section{IV. 試料の分析方法}

鉱物の化学組成は, 秋田県資源技術開発機構(財)お よび北海道大学理学研究科の X 線マイクロアナライ ザー（日本電子社製 JXA-8600, JCMA-733）を使用し, 加速電圧 $15 \mathrm{kv}$, 試料電流 $2.5 \times 10^{-8} \mathrm{~A}$ の条件で測定し た。全岩の主成分は, ガラスビード法により秋田大学 工学資源学部の蛍光 X 線分析装置 (理学電気工業社製 System 3070)を用いて分析した。全岩の微量成分につ いては, 下記と同様の方法で酸分解した溶液を ICP 質 量分析装置（VG 社製 $\mathrm{QII} \Omega$ ）で分析した。
全岩および鉱物の同位体分析の手順は以下の通りで ある。試料表面の風化部分を除去したあと, タングス テン乳鉢で $1 \mathrm{~mm}$ 以下の鉱物粒子に分離した。鉱物試 料については, 双眼実体顕微鏡によって新鮮なものを 選び, カンラン石と斜方輝石をそれぞれ $5 \mathrm{~g}$ 以上, 単斜 輝石を $0.5 \mathrm{~g}$ 以上集めた。この後, 鉱物抢よび全岩試料 に酸 (2 規定塩酸, $5 \%$ フッ化水素酸) を加え $80^{\circ} \mathrm{C} て ゙ 10$ 分間加温し, 続いて 2 段蒸留水で約 1 時間超音波洗浄 を行った。この作業を数回繰り返した後, 試料を乾燥 し,タングステン乳鉢およびメノウ乳鉢で粉末にした。 酸分解に用いる試料の量は, 全岩 $=100 \mathrm{mg}$, カンラン 石 $=300 \mathrm{mg}$, 斜方輝石 $=250 \mathrm{mg}$, 単斜輝石 $=50 \mathrm{mg}$ を 目安とした。これらを少量の混酸（超高純度のフッ化 水素酸 $0.6 \mathrm{ml}$, 過塩素酸 $1.8 \mathrm{ml}$ ) によって分解した。

$\mathrm{Rb} ， \mathrm{Sr}$ 抢よ゙ $\mathrm{Nd}$ の抽出法については，加々美ら (1982), Kagami et al. (1987) および山元・丸山 (1996) に従った。同位体比は, 秋田大学工学資源学部および 北海道大学理学研究科の質量分析装置 (フィニガン マット社製MAT 261，MAT 262）によって測定し た。 ${ }^{87} \mathrm{Sr} /{ }^{86} \mathrm{Sr}$ および ${ }^{143} \mathrm{Nd} /{ }^{144} \mathrm{Nd}$ 比は,それぞれ ${ }^{86} \mathrm{Sr} /{ }^{88} \mathrm{Sr}=0.1194,{ }^{146} \mathrm{Nd} /{ }^{144} \mathrm{Nd}=0.7219$ で規格化し た。 $\mathrm{Rb}$ と $\mathrm{Sr}$ の定量は ${ }^{87} \mathrm{Rb}^{-86} \mathrm{Sr}$ 混合スパイクを用い た同位体希釈法により行った。標準試料の同位体比お よび $\mathrm{Rb} \cdot \mathrm{Sr}$ 濃度の測定結果を Table 4 の脚注に示す。 試料の分解から抽出までを含めたブランクは, $\mathrm{Rb}=$ $0.05 \mathrm{ng}, \mathrm{Sr}=0.30 \mathrm{ng}$ および ${ }^{87} \mathrm{Sr} /{ }^{86} \mathrm{Sr}=0.7084$ であっ た。試料の $\mathrm{Sr}$ 同位体比に対するブランクの影響の程 度については, NBS 987 の測定値の標準偏差以内 (本 研究室では土0.0032\%）に収まるようにした。例えば， 最も $\mathrm{Sr}$ 濃度の低い試料番号 962 のカンラン石 $330 \mathrm{mg}$ に対するブランクの影響を計算すると, olv-1 と olv-2 の ${ }^{87} \mathrm{Sr} /{ }^{86} \mathrm{Sr}$ 比は真值よりもそれぞれ $0.0028 \%$, $0.0024 \%$ 高くなる。また ${ }^{87} \mathrm{Rb} /{ }^{86} \mathrm{Sr}$ 比はそれぞれ $0.82 \%, 0.99 \%$ 低くなる。

\section{V. 分析結果}

\section{1. 鉱物の化学組成}

代表的な分析値を Table 2 に示す。カンラン石と輝 石の $\mathrm{Mg} /(\mathrm{Mg}+\mathrm{Fe})$ 原子比 $(\mathrm{Mg} \#)$ を比較すると, 一 の目潟のカンラン岩のものは黒瀬のものよりもやや変 化が大きい(一の目潟; カンラン石 $=0.890 \sim 0.908$, 斜 方輝石 $=0.892 \sim 0.914$, 単斜輝石 $=0.910 \sim 0.921$ : 黒瀬; それぞれ 0.903〜0.910, 0.905〜0.917, 0.919 0.928)。ス ピネルの $\mathrm{Cr} /(\mathrm{Cr}+\mathrm{Al})$ 原子比 $(\mathrm{Cr} \#)$ も同様に一の目 潟のカンラン岩のほうが幅広い（一の目潟=0.19 
Table 2. Selected electron microprobe analyses of the constituent minerals of peridotite xenoliths from Ichinomegata and Kurose

\begin{tabular}{|c|c|c|c|c|c|c|c|c|c|c|c|c|c|c|c|c|c|c|}
\hline \multirow{3}{*}{$\frac{\text { No. }}{\text { Mineral }}$} & \multicolumn{18}{|c|}{ Ichinomegata } \\
\hline & \multicolumn{5}{|c|}{$\mathrm{N}-8$} & \multicolumn{4}{|l|}{$370-1$} & \multicolumn{4}{|l|}{ L-52 } & \multicolumn{5}{|l|}{961} \\
\hline & olv & opx & cpx & $\mathrm{sp}$ & amph & olv & opx & cpx & sp & olv & opx & cpx & $\mathrm{sp}$ & olv & opx & $\mathrm{cpx}$ & sp & amph \\
\hline$\overline{\mathrm{SiO}_{2}}$ & 40.54 & 54.65 & 52.18 & 0.00 & 44.76 & 40.14 & 54.18 & 51.13 & 0.02 & 40.49 & 55.95 & 52.01 & 0.03 & 40.97 & 56.01 & 52.27 & 0.01 & 44.35 \\
\hline $\mathrm{TiO}_{2}$ & 0.00 & 0.13 & 0.25 & 0.09 & 1.24 & 0.03 & 0.10 & 0.44 & 0.07 & 0.02 & 0.08 & 0.40 & 0.39 & 0.00 & 0.14 & 0.46 & 0.47 & 1.51 \\
\hline $\mathrm{Al}_{2} \mathrm{O}_{3}$ & 0.01 & 4.10 & 3.57 & 48.35 & 15.69 & 0.01 & 4.06 & 5.20 & 47.98 & 0.01 & 2.47 & 3.88 & 34.24 & 0.00 & 2.74 & 3.59 & 38.51 & 12.41 \\
\hline $\mathrm{Cr}_{2} \mathrm{O}_{3}$ & 0.03 & 0.52 & 0.67 & 16.32 & 1.18 & 0.01 & 0.64 & 1.17 & 18.89 & 0.01 & 0.52 & 0.96 & 35.04 & 0.01 & 0.45 & 0.85 & 25.96 & 1.44 \\
\hline $\mathrm{Fe}_{2} \mathrm{O}_{3}$ & & & & 5.89 & & & & & 3.13 & & & & 2.79 & & & & 5.99 & \\
\hline${ }^{*} \mathrm{FeO}$ & 10.54 & 7.03 & 2.75 & 8.09 & 4.02 & 10.57 & 6.67 & 2.86 & 12.04 & 9.35 & 6.18 & 3.01 & 12.25 & 9.10 & 5.70 & 2.68 & 10.41 & 3.89 \\
\hline $\mathrm{MnO}$ & 0.14 & 0.15 & 0.08 & 0.11 & 0.01 & 0.12 & 0.14 & 0.10 & 0.45 & 0.13 & 0.15 & 0.09 & 0.41 & 0.14 & 0.16 & 0.10 & 0.21 & 0.06 \\
\hline $\mathrm{MgO}$ & 47.65 & 32.61 & 16.59 & 20.27 & 17.85 & 49.78 & 33.44 & 16.28 & 17.85 & 50.93 & 34.98 & 17.42 & 16.86 & 50.42 & 34.01 & 17.07 & 17.95 & 18.46 \\
\hline $\mathrm{NiO}$ & 0.38 & 0.11 & 0.05 & 0.26 & 0.13 & - & - & - & - & - & - & - & - & 0.36 & 0.08 & 0.07 & 0.32 & 0.11 \\
\hline $\mathrm{CaO}$ & 0.06 & 0.60 & 23.37 & 0.00 & 11.96 & 0.09 & 0.71 & 22.97 & 0.00 & 0.05 & 0.67 & 22.52 & 0.00 & 0.08 & 0.64 & 22.54 & 0.03 & 11.59 \\
\hline $\mathrm{Na}_{2} \mathrm{O}$ & 0.01 & 0.02 & 0.38 & 0.00 & 2.24 & 0.01 & 0.01 & 0.55 & 0.01 & 0.03 & 0.03 & 0.35 & 0.02 & 0.00 & 0.00 & 0.33 & 0.00 & 2.53 \\
\hline $\mathrm{K}_{2} \mathrm{O}$ & 0.00 & 0.00 & 0.00 & 0.00 & 0.65 & 0.00 & 0.00 & 0.00 & 0.00 & 0.00 & 0.00 & 0.00 & 0.00 & 0.00 & 0.00 & 0.00 & 0.00 & 0.40 \\
\hline total & 99.37 & 99.93 & 99.90 & 99.38 & 99.71 & 100.74 & 99.96 & 100.68 & 100.44 & 101.01 & 101.04 & 100.64 & 102.01 & 101.09 & 99.93 & 99.96 & 99.86 & 96.74 \\
\hline $\mathrm{Mg \#}$ & 0.890 & 0.892 & 0.915 & 0.817 & 0.888 & 0.894 & 0.899 & 0.910 & 0.725 & 0.907 & 0.910 & 0.912 & 0.710 & 0.908 & 0.914 & 0.919 & 0.755 & 0.894 \\
\hline \multirow[t]{2}{*}{$\mathrm{Cr} \#$} & & & & 0.185 & & & & & 0.209 & & & & 0.407 & & & & 0.311 & \\
\hline & & & & & & Kurose & & & & & & & & & & & & \\
\hline No. & 962 & & & & & $\mathrm{~K}-1$ & & & & $\mathrm{~K}-4$ & & & & $\mathrm{~K}-6$ & & & & \\
\hline Mineral & olv & opx & $\mathrm{cpx}$ & $\mathrm{sp}$ & amph & olv & opx & $\operatorname{cpx}$ & $\mathrm{sp}$ & olv & opx & $\operatorname{cpx}$ & $\mathrm{sp}$ & olv & opx & $\operatorname{cpx}$ & $\mathrm{sp}$ & \\
\hline$\overline{\mathrm{SiO}_{2}}$ & 41.22 & 56.11 & 52.01 & 0.00 & 44.43 & 39.88 & 54.87 & 52.15 & 0.03 & 41.10 & 55.84 & 52.98 & 0.01 & 40.64 & 55.39 & 52.53 & 0.04 & \\
\hline $\mathrm{TiO}_{2}$ & 0.00 & 0.14 & 0.53 & 0.50 & 1.53 & 0.00 & 0.07 & 0.19 & 0.13 & 0.00 & 0.03 & 0.11 & 0.14 & 0.01 & 0.05 & 0.13 & 0.12 & \\
\hline $\mathrm{Al}_{2} \mathrm{O}_{3}$ & 0.00 & 2.71 & 3.77 & 38.25 & 12.61 & 0.00 & 3.24 & 3.51 & 45.31 & 0.00 & 3.23 & 3.53 & 40.53 & 0.00 & 3.37 & 3.17 & 41.20 & \\
\hline $\mathrm{Cr}_{2} \mathrm{O}_{3}$ & 0.00 & 0.52 & 0.96 & 26.60 & 1.50 & 0.04 & 0.55 & 0.79 & 26.29 & 0.00 & 0.55 & 0.92 & 26.82 & 0.02 & 0.55 & 0.65 & 27.21 & \\
\hline $\mathrm{Fe}_{2} \mathrm{O}_{3}$ & & & & 6.40 & & & & & 0.13 & & & & 3.11 & & & & 2.58 & \\
\hline${ }^{*} \mathrm{FeO}$ & 9.21 & 5.99 & 2.54 & 10.42 & 4.03 & 9.62 & 6.13 & 2.71 & 11.40 & 8.85 & 5.49 & 2.42 & 10.13 & 9.53 & 6.24 & 2.68 & 11.44 & \\
\hline $\mathrm{MnO}$ & 0.14 & 0.16 & 0.09 & 0.21 & 0.07 & 0.09 & 0.12 & 0.12 & 0.45 & 0.14 & 0.15 & 0.10 & 0.20 & 0.18 & 0.13 & 0.10 & 0.21 & \\
\hline $\mathrm{MgO}$ & 50.47 & 34.22 & 16.54 & 18.14 & 18.43 & 50.29 & 34.14 & 17.15 & 18.43 & 50.35 & 34.03 & 17.44 & 18.57 & 49.11 & 33.51 & 17.33 & 17.63 & \\
\hline $\mathrm{NiO}$ & 0.38 & 0.08 & 0.06 & 0.32 & 0.12 & - & - & - & - & 0.35 & 0.09 & 0.06 & 0.30 & 0.36 & 0.07 & 0.03 & 0.30 & \\
\hline $\mathrm{CaO}$ & 0.07 & 0.65 & 23.62 & 0.02 & 11.49 & 0.07 & 0.87 & 23.11 & 0.01 & 0.09 & 0.92 & 22.15 & 0.02 & 0.08 & 0.84 & 23.15 & 0.01 & \\
\hline $\mathrm{Na}_{2} \mathrm{O}$ & 0.00 & 0.00 & 0.23 & 0.00 & 2.47 & 0.00 & 0.04 & 0.38 & 0.02 & 0.00 & 0.00 & 0.42 & 0.00 & 0.00 & 0.02 & 0.27 & 0.00 & \\
\hline $\mathrm{K}_{2} \mathrm{O}$ & 0.00 & 0.00 & 0.00 & 0.00 & 0.34 & 0.00 & 0.00 & 0.00 & 0.00 & 0.00 & 0.00 & 0.00 & 0.00 & 0.00 & 0.00 & 0.00 & 0.00 & \\
\hline total & 101.49 & 100.58 & 100.34 & 100.86 & 97.02 & 99.99 & 100.03 & 100.11 & 102.17 & 100.88 & 100.35 & 100.11 & 99.85 & 99.94 & 100.16 & 100.06 & 100.74 & \\
\hline Mg\# & 0.907 & 0.911 & 0.921 & 0.756 & 0.891 & 0.903 & 0.908 & 0.919 & 0.742 & 0.910 & 0.917 & 0.928 & 0.777 & 0.902 & 0.905 & 0.920 & 0.733 & \\
\hline $\mathrm{Cr} \#$ & & & & 0.318 & & & & & 0.280 & & & & 0.307 & & & & 0.307 & \\
\hline
\end{tabular}

*, total iron as $\mathrm{FeO}$ except spinel; $\mathrm{Mg} \#, \mathrm{Mg} /(\mathrm{Mg}+$ total $\mathrm{Fe})$ atomic ratio except spinel $; \mathrm{Mg} /(\mathrm{Mg}+$ $\mathrm{Fe}$ ) for spinel in which $\mathrm{Fe}^{2+}$ and $\mathrm{Fe}^{3+}$ were calculated assuming stoichiometry $\mathrm{Cr} \#, \mathrm{Cr} /(\mathrm{Cr}+\mathrm{Al})$ atomic ratio.

Mineral abbreviations as for Table 1.

〜 0.41 ; 黒瀬 $=0.28 \sim 0.31)$ 。このことは, 既存のスピネ ルの $\mathrm{Cr}$ \#の特徵とも一致する（一の目潟 $=0.07 \sim 0.53$; Abe et al., 1998: 黒瀬=0.3 前後; Arai and Hirai, 1983)。

\section{2. 全岩化学組成}

(1) 主成分

それぞれの岩石試料を三つに分割し，鉱物のハンド ピック, 薄片作製および全岩粉末試料の作製を行った。 比較的大きな試料を選んだとはいえ, 分割した試料片 どうしが均質で同じ組成を示すかどうかを検討してお く必要がある。そこで, 薄片中の各鉱物の化学組成 (Table 2) の荷重平均が全岩分析值を満足するように, 原点を通る重回帰計算を行い, 構成鉱物の化学モード (chemical mode; Wright and Doherty, 1970) を求 めた (Table 3)。なお $\mathrm{P}_{2} \mathrm{O}_{5}, \mathrm{Cr}_{2} \mathrm{O}_{3}, \mathrm{NiO}$ および微量の 角閃石はこの計算から除いた。Fig. 2 は, 化学モードと 薄片のポイントカウントによるモード (optical mode ; Wright and Doherty，1970）を比較したものである。 両モードはおおむね一致しているので，薄片および全 岩分析に用いた二つの分割試料は，両者とも岩石の平 均的な組成を表しているといえる。ただし，スピネル については差の大きいものもある。これは $\mathrm{Cr}$ を計算 に考慮していないことや, スピネルの含有量が少いこ とに由来する種々の誤差によると思われる。試料中に スピネルのような少数の鉱物や，カンラン石あるいは 斜方輝石のような粗粒の結晶が偏在していれば, 薄片 
Table 3. Whole rock major and trace element compositions of peridotite xenoliths from Ichinomegata and Kurose

\begin{tabular}{|c|c|c|c|c|c|c|c|c|}
\hline \multicolumn{6}{|c|}{ Ichinomegata } & \multicolumn{3}{|l|}{ Kurose } \\
\hline No. & $\mathrm{N}-8$ & $370-1$ & $\mathrm{~L}-52$ & 961 & 962 & $\mathbf{K}-1$ & $\mathrm{~K}-4$ & $\mathrm{~K}-6$ \\
\hline \multicolumn{9}{|l|}{ (wt.\%) } \\
\hline $\mathrm{SiO}_{2}$ & 44.80 & 44.01 & 41.75 & 43.90 & 43.78 & 44.80 & 43.35 & 43.27 \\
\hline $\mathrm{TiO}_{2}$ & 0.09 & 0.09 & 0.04 & 0.09 & 0.09 & 0.07 & 0.03 & 0.03 \\
\hline $\mathrm{Al}_{2} \mathrm{O}_{3}$ & 2.92 & 2.27 & 0.81 & 1.28 & 1.32 & 1.81 & 1.28 & 1.77 \\
\hline${ }^{*} \mathrm{Fe}_{2} \mathrm{O}_{3}$ & 10.63 & 10.15 & 9.17 & 10.64 & 10.31 & 9.76 & 10.06 & 9.83 \\
\hline $\mathrm{MnO}$ & 0.16 & 0.15 & 0.13 & 0.15 & 0.15 & 0.15 & 0.15 & 0.15 \\
\hline $\mathrm{MgO}$ & 38.10 & 39.85 & 46.27 & 42.66 & 42.14 & 41.45 & 42.47 & 41.30 \\
\hline $\mathrm{CaO}$ & 2.76 & 2.71 & 0.45 & 1.05 & 1.35 & 1.59 & 1.89 & 1.77 \\
\hline $\mathrm{Na}_{2} \mathrm{O}$ & 0.36 & 0.22 & 0.00 & 0.05 & 0.07 & 0.07 & 0.09 & 0.07 \\
\hline $\mathrm{K}_{2} \mathrm{O}$ & 0.01 & 0.00 & 0.01 & 0.00 & 0.00 & 0.00 & 0.00 & 0.00 \\
\hline $\mathrm{P}_{2} \mathrm{O}_{5}$ & 0.01 & 0.01 & 0.01 & 0.01 & 0.01 & 0.00 & 0.01 & 0.00 \\
\hline total & 99.82 & 99.45 & 98.64 & 99.82 & 99.21 & 99.70 & 99.32 & 98.20 \\
\hline \multicolumn{9}{|c|}{ Chemical Mode (wt.\%) ${ }^{* *}$} \\
\hline olv & 54.4 & 57.0 & 78.8 & 64.7 & 63.5 & 56.4 & 68.0 & 64.7 \\
\hline opx & 30.8 & 28.8 & 16.4 & 27.4 & 26.9 & 35.5 & 20.4 & 24.4 \\
\hline $\operatorname{cpx}$ & 11.4 & 10.7 & 1.3 & 3.7 & 4.7 & 5.4 & 7.5 & 6.6 \\
\hline sp & 2.4 & 1.4 & 0.7 & 2.3 & 2.2 & 1.4 & 1.7 & 2.2 \\
\hline \multicolumn{9}{|l|}{ (ppm) } \\
\hline${ }^{* * *} \mathrm{Rb}$ & - & - & - & - & 0.03 & 0.04 & 0.02 & 0.01 \\
\hline $\mathrm{Sr}$ & 6.85 & 3.23 & 1.65 & 3.56 & 4.03 & 1.31 & 4.54 & 1.44 \\
\hline${ }^{* * *} \mathrm{~S} r$ & - & - & - & - & 3.33 & 1.24 & 6.37 & 5.88 \\
\hline $\mathrm{Zr}$ & 3.49 & 1.42 & 1.73 & 2.56 & 2.29 & 0.88 & 0.53 & 1.49 \\
\hline $\mathrm{Y}$ & 2.11 & 2.39 & 0.50 & 0.66 & 0.85 & 0.94 & 0.71 & 0.73 \\
\hline $\mathrm{Nb}$ & 0.31 & 0.07 & 0.18 & 0.37 & 0.25 & 0.03 & 0.06 & 0.84 \\
\hline $\mathrm{Ba}$ & 5.56 & 2.57 & 0.89 & 0.92 & 0.61 & 0.23 & 0.10 & 1.33 \\
\hline La & 0.29 & 0.11 & 0.13 & 0.07 & 0.08 & 0.05 & 0.22 & 0.10 \\
\hline $\mathrm{Ce}$ & 0.61 & 0.24 & 0.33 & 0.18 & 0.62 & 0.15 & 0.40 & 0.19 \\
\hline $\mathrm{Nd}$ & 0.39 & 0.23 & 0.22 & 0.16 & 0.20 & 0.18 & 0.19 & 0.10 \\
\hline $\mathrm{Sm}$ & 0.14 & 0.13 & 0.06 & - & - & 0.08 & 0.05 & 0.03 \\
\hline $\mathrm{Eu}$ & 0.06 & 0.06 & 0.02 & - & - & 0.02 & 0.01 & 0.01 \\
\hline $\mathrm{Gd}$ & 0.21 & 0.15 & 0.07 & - & - & 0.10 & 0.06 & 0.05 \\
\hline $\mathrm{Tb}$ & 0.05 & - & 0.01 & - & - & 0.02 & 0.01 & 0.01 \\
\hline Dy & 0.37 & 0.33 & 0.09 & - & - & 0.15 & 0.10 & 0.11 \\
\hline Ho & 0.08 & - & 0.02 & - & - & 0.04 & 0.02 & 0.03 \\
\hline $\mathrm{Er}$ & 0.27 & 0.24 & 0.06 & - & - & 0.11 & 0.09 & 0.10 \\
\hline $\mathrm{Tm}$ & 0.04 & - & 0.01 & - & - & 0.02 & 0.02 & 0.02 \\
\hline $\mathrm{Yb}$ & 0.28 & 0.26 & 0.07 & - & - & 0.14 & 0.11 & 0.12 \\
\hline $\mathrm{Lu}$ & 0.04 & 0.04 & 0.01 & - & - & 0.02 & 0.02 & 0.02 \\
\hline $\mathrm{Hf}$ & 0.13 & 0.05 & 0.06 & - & - & 0.04 & 0.01 & 0.08 \\
\hline $\mathrm{Ta}$ & 0.67 & 0.13 & 0.41 & - & - & 0.17 & 0.37 & 0.32 \\
\hline $\mathrm{Pb}$ & 0.55 & - & 0.35 & 0.13 & 0.10 & 0.61 & 1.55 & 1.24 \\
\hline
\end{tabular}

*, total iron as $\mathrm{Fe}_{2} \mathrm{O}_{3}$; ${ }^{* *}$, calculated by a leastsquares method using major element compositions of whole rocks and minerals; ${ }^{* * *}$, obtained by isotope dilution analysis.

Mineral abbreviations as for Table 1.

のモードよりも, 多量の試料から得られた全岩分析值 に基づく化学モードのほうがより平均的な鉱物組成を 代表すると考えられる。以下に全岩の主成分の特徴を 述べる。

$\mathrm{MgO}$ 変化図において, $\mathrm{Al}_{2} \mathrm{O}_{3}, \mathrm{TiO}_{2}$ および $\mathrm{CaO}$ は, ほかの地域のカンラン岩捕獲岩と同様に（例えば Maaløe and Aoki, 1977; Frey and Prinz, 1978;

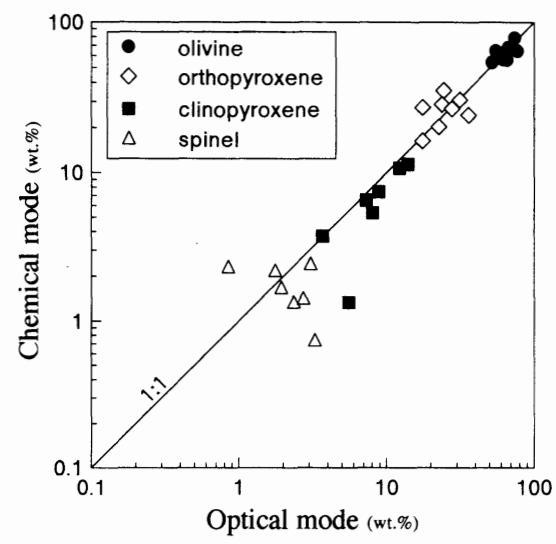

Fig. 2. Optical mode-chemical mode diagram of peridotite xenoliths from Ichinomegata and Kurose using the data in Tables 1-3. The optical mode was recalculated to weight $\%$ using mineral densities.

McDonough, 1990）負の相関を示す (Fig. 3)。モード 組成と鉱物の固溶体組成の変化幅から予想されるよう に, 本研究で用いた一の目潟のカンラン岩の $\mathrm{MgO}$ weight (wt.) \% は変化が大きく (38～46 wt.\%), 既存 の分析值の範囲 (39 47 wt.\%: Kuno and Aoki, 1970; Aoki and Shiba, 1973) にほぼ重なる。したがっ て今回の 5 試料は一の目潟のカンラン岩の多様な組成 をそれぞれ代表する試料であるといえる。黒瀬のカン ラン岩は, モード組成と鉱物の固溶体組成が比較的均 質なことと調和的に狭い範囲にある（ $\mathrm{MgO}=41 \sim 43$ wt.\%)。以上のことは Mg/Si 比- Ca/Si 比図 (Fig. 4) についても同様で,一の目潟のカンラン岩は terres trial array（Hart and Zindler, 1986）のほとんどを覆 うほど組成範囲が広い。いっぽう黒瀬のカンラン岩は 枯渴度 $15 \%$ 以上の狭い範囲にプロットされる。

\section{(2) 微量成分}

両地域のカンラン岩の微量元素濃度 (Table 3) を始 源的マントルの值 (Hofmann, 1988) で規格化して Fig. 5 に示す。同様に Leedey コンドライト (Masuda et al., 1973）で規格化した希土類元素（REE）パターン を Fig. 6 に示す。主成分から予想される枯渇度（Fig. 4) と調和的に, 両地域の試料とも微量元素および REE のレベルは始源的マントルやコンドライトより低い。

一の目潟のカンラン岩のうち，始源的マントルある いはコンドライトのレベルに最も近いのは試料番号 N-8である (Figs. 5,6)。このことはN-8の単斜輝石 のモード量が最も多いこと, また $\mathrm{MgO} や \mathrm{Mg} / \mathrm{Si}$ 比が 最も低いことと調和的である(Table 1, Figs. 3, 4)。そ 


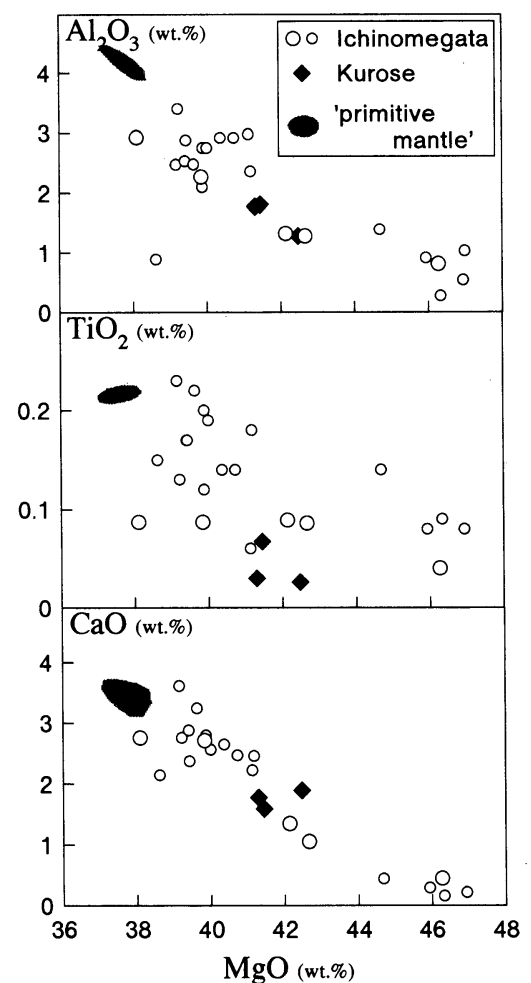

Fig. 3. $\mathrm{MgO}-\mathrm{Al}_{2} \mathrm{O}_{3}, \mathrm{TiO}_{2}$ and $\mathrm{CaO}$ variation diagrams of peridotite xenoliths from Ichinomegata and Kurose. The data shown by small open circles are from Kuno and Aoki (1970) and Aoki and Shiba (1973). The proposed primitive mantle compositions (shaded) from Jagoutz et al. (1979), Wänke (1981), Hart and Zindler (1986) and McDonough (1990).

の他の試料は不規則なパターンを示し, U 字型の REE パターンを示すものもある（Fig. 6)。ただし，Y と $\mathrm{MgO}$ の間に比較的よい相関がある $(\mathrm{r}=0.863, \mathrm{n}=5)$ 。 また中〜重希土類元素 $(\mathrm{M} \sim \mathrm{HREE})$ と $\mathrm{MgO}$ の間の相 関もよい。このことは, Tanaka and Aoki (1981) の 結果とも調和的である。彼らは, Dy-value がREEの 変化を最もよく表し，全岩の $\mathrm{Mg}$ \#との間に負の相関 があることから，この值を分化尺度として用いた。

黒瀬のカンラン岩の HREE の変化は小さく, M 〜HREE はすべて左下がりを示す (Fig. 6)。ただし試 料番号 K-4 と K-6 は軽希土類元素 (LREE) に富むの で, V 字型のパターンを示す。このように LREE は変 化が大きく, La と Ce は K-1, K-6, K-4 の順で増加 し, $\mathrm{La} / \mathrm{Yb}$ 比もこの順に高くなる。その他のインコン

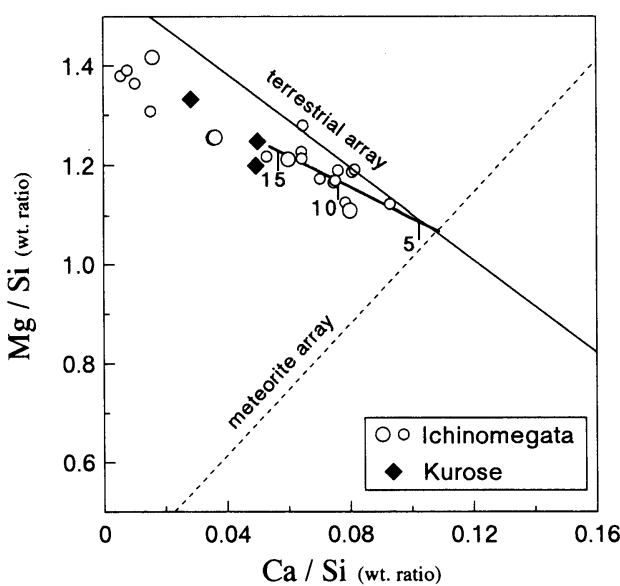

Fig. 4. $\mathrm{Mg} / \mathrm{Si}-\mathrm{Ca} / \mathrm{Si}$ diagram of peridotite xenoliths from Ichinomegata and Kurose. The plotted data are recalculated for $\mathrm{Ca} /$ $\mathrm{Al}$ ratio to be 1.09 by subtraction of clinopyroxene (Zindler and Hart, 1986). Symbols as in Fig. 3. The terrestrial and meteorite arrays from Hart and Zindler (1986). A heavy solid line with tick marks is a trajectory of residual compositions resulting from melt removal (\%) (Hart and Zindler, 1986).

パチブル元素のパターンは不規則である (Fig. 5)。Fig. 6 にみられる LREE のばらつきは, Abe et al. (1998) による単斜輝石の REE パターンにも認められる。全 岩と単斜輝石の REE パターンが類似していること は, 無水スピネルカンラン岩中の REE が単斜輝石に 濃集すること（McDonough et al., 1992）によると考 えられる。

以上の全岩化学組成の特徵をまとめると, 主成分に 関して, 一の目潟のカンラン岩は変化幅が広く, 黒瀬 のカンラン岩は枯渴的で変化幅が比較的狭い。このこ とは M〜HREEについても同様である。これに対し， LREE およびその他のインコンパチブル元素は, 両地 域のカンラン岩とも不規則なパターンを示す。

\section{Sr および Nd 同位体組成}

(1) $\mathrm{Rb} \cdot \mathrm{Sr}$ 濃度および $\mathrm{Sr} \cdot \mathrm{Nd}$ 同位体比

構成鉱物および全岩の測定結果を Table 4 に示す。 同じ鉱物種でも別々にハンドピックした場合は, $\mathrm{cpx}^{-}$ 1 と $\mathrm{cpx}-2$ のように番号を付したが，どちらもほぼ同 じ濃度と同位体比を示すことが多い。測定值がやや異 なる場合には, ${ }^{87} \mathrm{Rb} /{ }^{86} \mathrm{Sr}$ 比の高いものほど ${ }^{87} \mathrm{Sr} /{ }^{86} \mathrm{Sr}$ 比が高い傾向にあるので, アイソクロンに沿ってプ ロットされる。ただし，カンラン石の場合は $\mathrm{Rb}$ と $\mathrm{Sr}$ 

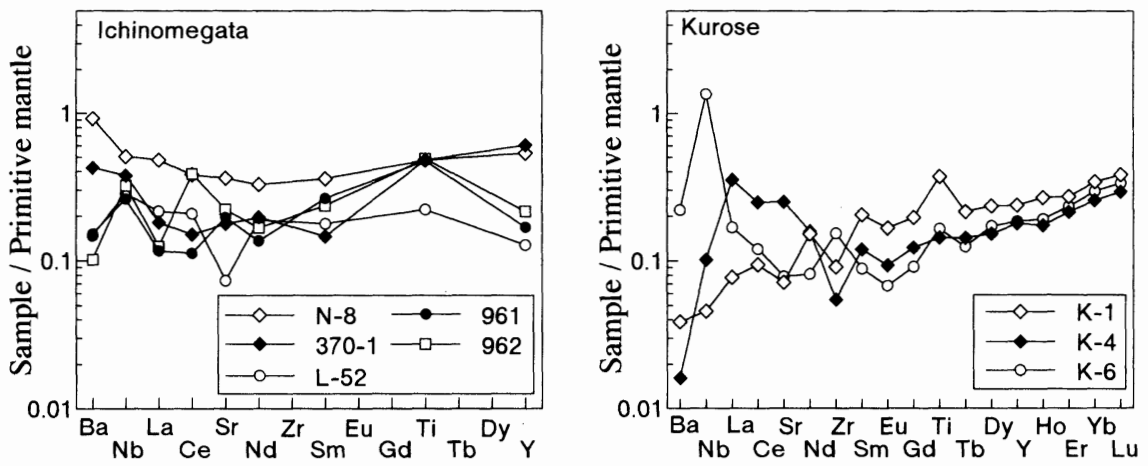

Fig. 5. Primitive mantle-normalized trace elements abundance patterns of peridotite xenoliths from Ichinomegata and Kurose.
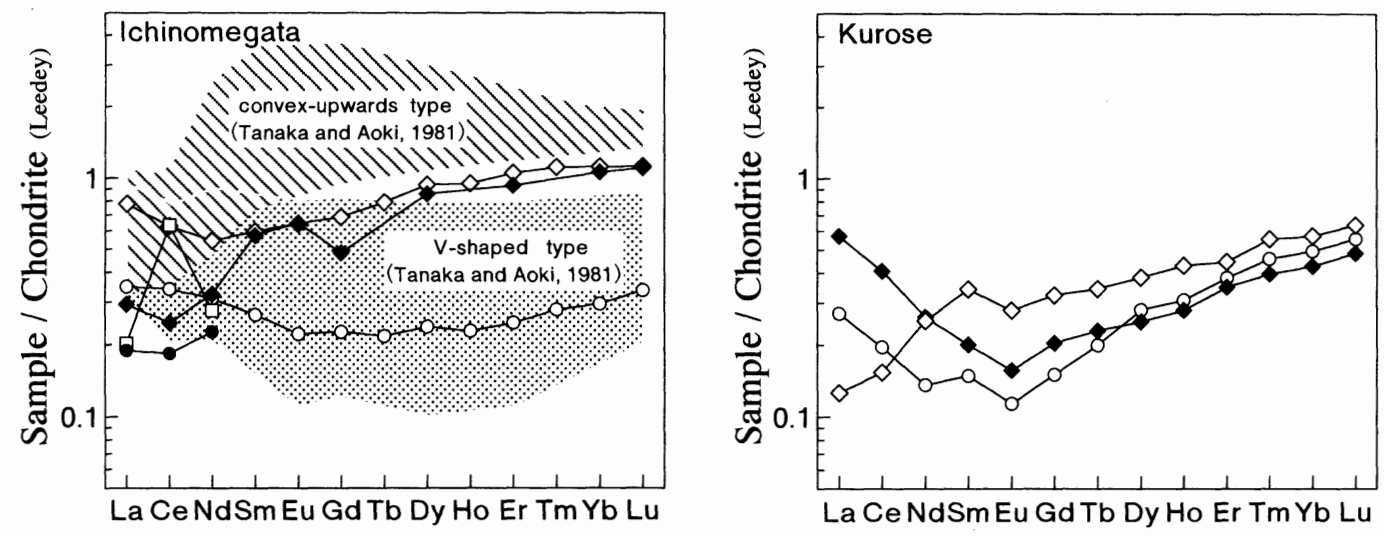

Fig. 6. Chondrite-normalized REE patterns of peridotite xenoliths from Ichinomegata and Kurose. Symbols as in Fig. 5.

が極微量のため, 試料番号 962 の olv-1 と olv-2 のよ うに, 両元素のわずかな濃度の違いにより ${ }^{87} \mathrm{Rb} /{ }^{86} \mathrm{Sr}$ 比が大きく変化する。

構成鉱物はそれぞれ特徵的な $\mathrm{Sr}$ 濃度を示す（Fig. 7)。Fig. 7 には比較のために, 大陸地域に産するカンラ ン岩捕獲岩の構成鉱物の $\mathrm{Rb}$ および $\mathrm{Sr}$ 濃度の範囲を 加えた。一般に, 単斜輝石, 斜方輝石, カンラン石の 順に Sr 濃度が減少し $\mathrm{Rb} / \mathrm{Sr}$ 比は高くなる。一の目潟 と黒瀬のカンラン岩の場合も同様の傾向を示すが，大 陸地域に比べ $\mathrm{Sr}$ 濃度が低い。このことは Abe et al. （1998）による単斜輝石の SIMS 分析の結果とも調和 的である。また一の目潟と黒瀬を比較すると, 後者は $\mathrm{Rb}$ 濃度が低い傾向にある。

一の目潟のカンラン岩の $\mathrm{Sr}$ 同位体比は, 単斜輝石 $\rightarrow$ 斜方輝石 $\rightarrow$ カラン石の順に高くなる（0.7033～34 $\rightarrow 0.7036 \sim 40 \rightarrow 0.7040 \sim 66$, Table 4)。黒瀬のカンラ ン岩のカンラン石は Sr 濃度がきわめて低いため同位
体比を決定できなかったが (例えば K-6 のカンラン石 は $20 \mathrm{ppb}$ 以下), 輝石については一の目潟のカンラン 岩の場合と同様に，単斜輝石 $\rightarrow$ 斜方輝石の順に Sr 同 位体比が高くなる $(0.7034 \sim 43 \rightarrow 0.7038 \sim 55$, Table 4)。以上のような鉱物間の同位体的非平衡はアイソク ロンを形成していることによる。このうち単斜輝石は, $\mathrm{Sr}$ に対して Rbがきわめて少ないので, 各アイソクロ ンの Sr 同位体比初生值に近い值を示す (Figs. 8, 9)。 そこで単斜輝石の $\mathrm{Sr}$ 同位体比に注目すると, 一の目 潟のカンラン岩はほぼ一定であるが, 黒瀬のカンラン 岩は変化が大きい。このことは, 両地域のカンラン岩 の本質的な違いを示すものとして注目される。な啱 石記載の項で一括して述べたように, 黑瀬のカンラン 岩試料の間に特に組織の違いは認められない。 $\mathrm{Nd}$ 同 位体比については, 一の目潟のカンラン岩試料 961 と 962 の単斜輝石のみを測定したが, Srの場合と同様に ほぼ類似した值を示す（0.512771〜0.512834, Table 
Table 4. Whole rock and mineral isotopic compositions of peridotite xenoliths from Ichinomegata and Kurose

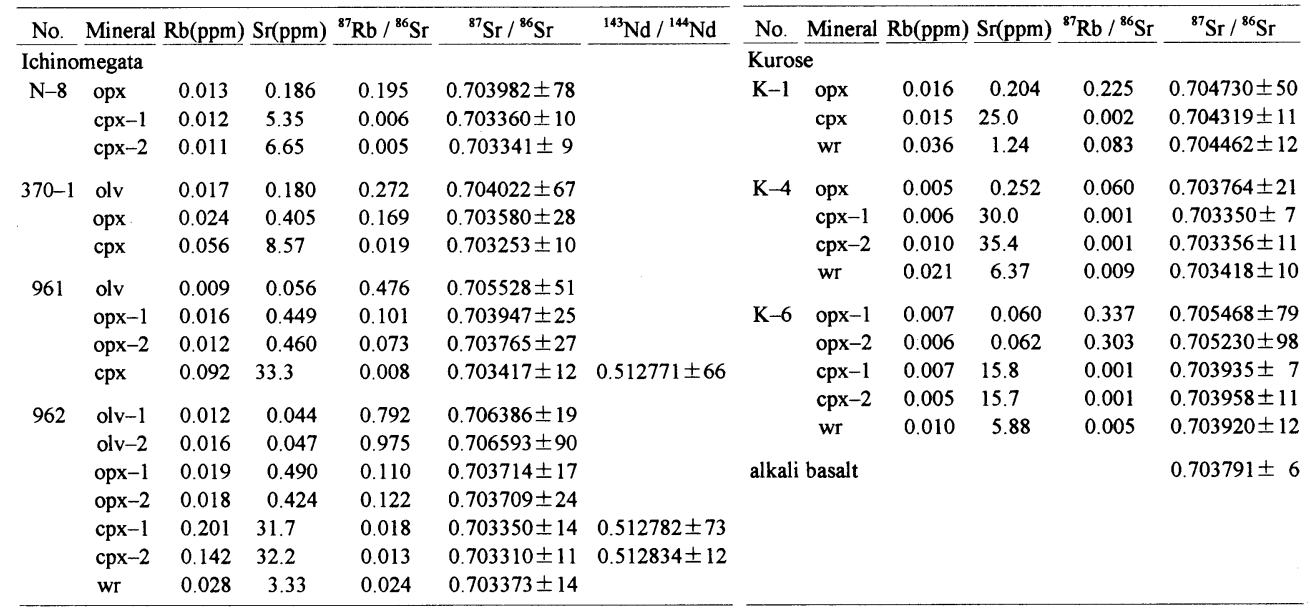

Mineral abbreviations as for Table 1 except wr, whole rock. Quoted errors for isotopic ratio are $2 \sigma$ (errors at $95 \%$ confidence limits). Standard results as follows : ${ }^{87} \mathrm{Sr} /{ }^{86} \mathrm{Sr}$; NBS $987=0.710240 \pm 7$, JB$1 \mathrm{a}=0.704100 \pm 7, \mathrm{JP}-1=0.706637 \pm 18,{ }^{143} \mathrm{Nd} /{ }^{144} \mathrm{Nd}$; La Jolla $=0.511829 \pm 14 . \quad \mathrm{Rb}$ ppm by isotope dilution analysis; JB- $1 \mathrm{a}=41.3 \pm 0.06(1 \sigma, \mathrm{n}=5), \mathrm{JP}-1=0.320 \pm 0.006(\mathrm{n}=3) \quad(0.335 \pm 0.008, \mathrm{n}=3$ by ICP-MS $), \mathrm{Sr}$ ppm by isotope dilution analysis; JB-1a=447.7 $\pm 0.63(n=4), J P-1=0.602 \pm 0.003 \quad(n=3)(0.580 \pm 0.004$, $\mathrm{n}=3$ by $\mathrm{ICP}-\mathrm{MS}$ )

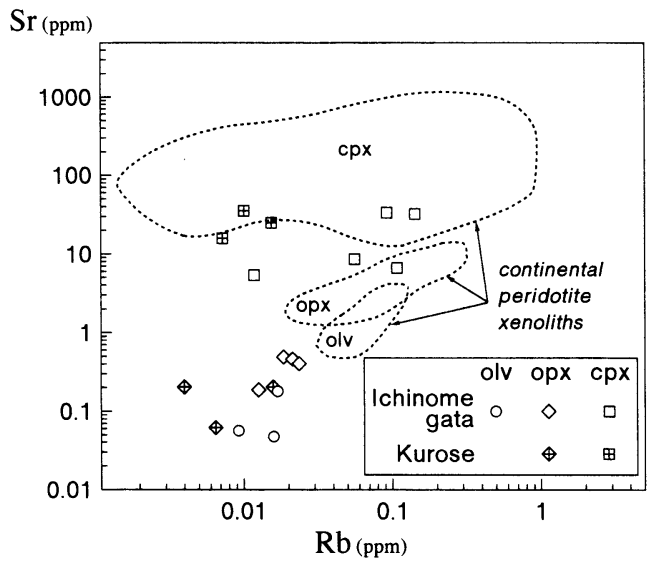

Fig. 7. $\mathrm{Rb}$ and $\mathrm{Sr}$ concentrations of constituent minerals in peridotite xenoliths from Ichinomegata, Kurose and other localities. Data for the continental peridotite xenoliths from Stueber and Ikramuddin (1974), Burwell (1975), Richardson et al. (1985), Stosch et al. (1986), Galer and O' Nions (1989), Ionov and Jagoutz (1989), Song and Frey (1989), Ionov et al. (1992), Tatsumoto et al. (1992), Günther and Jagoutz (1994). All analytical data are by isotope dilution analysis.
4)。

（2） $\mathrm{Rb}-\mathrm{Sr}$ 鉱物アイソクロン年代

上の結果からアイソクロン年代を得た (Table 5)。一 の目潟の試料番号 962 と黒瀬の全試料については全岩 の測定值も加えた。年代および同位体比初生值の計算 方法は, York (1966) の計算式を用いた川野 (1994)の プログラムに基づいた。 ${ }^{87} \mathrm{Rb}$ の壊変定数は $1.42 \times$ $10^{-11} / \mathrm{y}$ (Steiger and Jäger, 1977）を用いた。年代の 誤差は $2 \sigma て ゙$ 示した。その際, ${ }^{87} \mathrm{Rb} /{ }^{86} \mathrm{Sr}$ おび ${ }^{87} \mathrm{Sr} /$

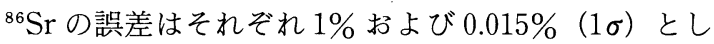
た。

一の目潟のカンラン岩は 200〜300 Ma の年代を示 した(Table 5, Fig. 8)。4 個の試料のうち試料番号 961 を除くと, 残りの 3 試料は $200 \sim 250 \mathrm{Ma}$ の比較的狭い 範囲にある。 4 試料のすべての測定値から一つのアイ ソクロンを求めると $256.9 \pm 26.0 \mathrm{Ma}(\mathrm{MSWD}=4.0)$, また Sr 同位体比初生值は $0.703311 \pm 0.000123$ となっ た。

黒瀬のカンラン岩のアイソクロンはカンラン石を欠 くが, 全岩の測定值はアイソクロン上の単斜輝石と斜 方輝石の間に位置する。3 試料のアイソクロンはそれ ぞれ 130, 313 および $487 \mathrm{Ma}$ を示し (Table 5, Fig. 9), 一の目潟の場合と対照的に試料ごとに年代と初生值が 

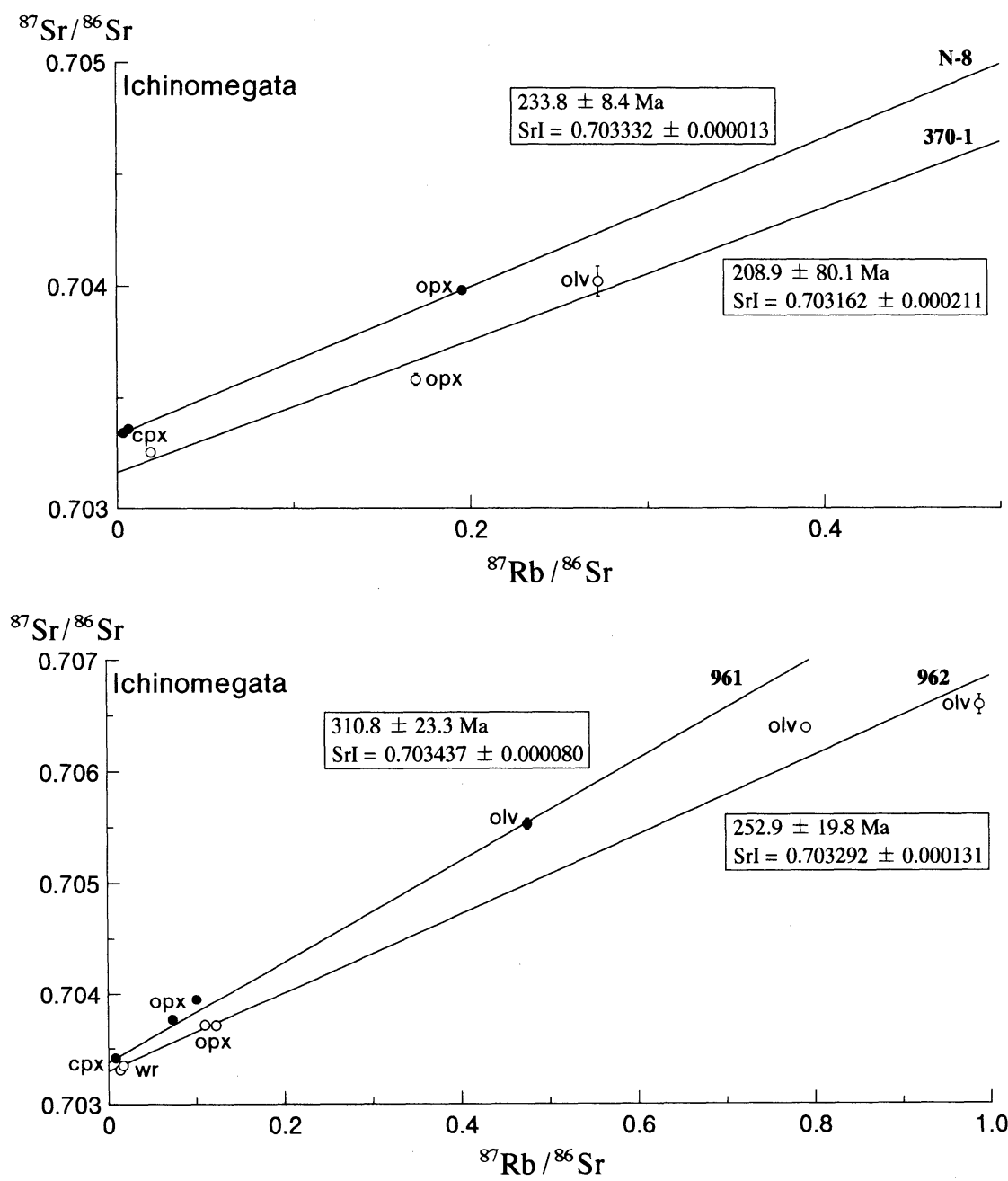

Fig. 8. $\mathrm{Rb}-\mathrm{Sr}$ isochron diagrams for Ichinomegata peridotite xenoliths. Vertical lines show error at $2 \sigma$ level. Abbreviations as for Table 4 except SrI, initial ${ }^{87} \mathrm{Sr} /{ }^{86} \mathrm{Sr}$ ratio.

大きく異なる。

\section{VI. 議論}

1. 鉱物アイソクロン年代について

カンラン岩捕獲岩の構成鉱物中の $\mathrm{Rb}, \mathrm{Sr}, \mathrm{Sm}$ およ び Nd は極めて少量である。そのため同位体分析に際 しては污染の問題がある。またマントルの温度・圧力 条件に関連して閉鎖温度の問題もある。ブランクの影 響についてはすでに述べたので，ここでは天然におけ る活染について考える。本研究では, ほぼ断口からな る鉱物粒子だけを双眼実体顕微鏡によってハンドピッ クした。さらにこれを酸で十分に洗浄したので, 風化
など地表条件における污染の可能性はほとんどない。 また以下のように母岩からの污染も考元られない。一 の目潟のカンラン岩の単斜輝石の $\mathrm{Sr}$ 同位体比 (0.70325 42) は比較的一定で, 母岩の值 (0.70351 65; Sakuyama and Koyaguchi, 1984）と類似する。この ことが母岩マグマとの十分な $\mathrm{Sr}$ の拡散の結果だとす ると, 単斜輝石よりも $\mathrm{Sr}$ の少ない斜方輝石とカンラ ン石の同位体的な平衡はきわめて容易に達成されてい るはずである。しかし，これらの鉱物の $\mathrm{Sr}$ 同位体比は 母岩よりも十分に高い。黑瀬のカンラン岩試料 K-6に ついても同様である。さらに一の目潟, 黒瀬の両カン ラン岩とも, Sr の濃度と同位体比の関係からは構成鉱 


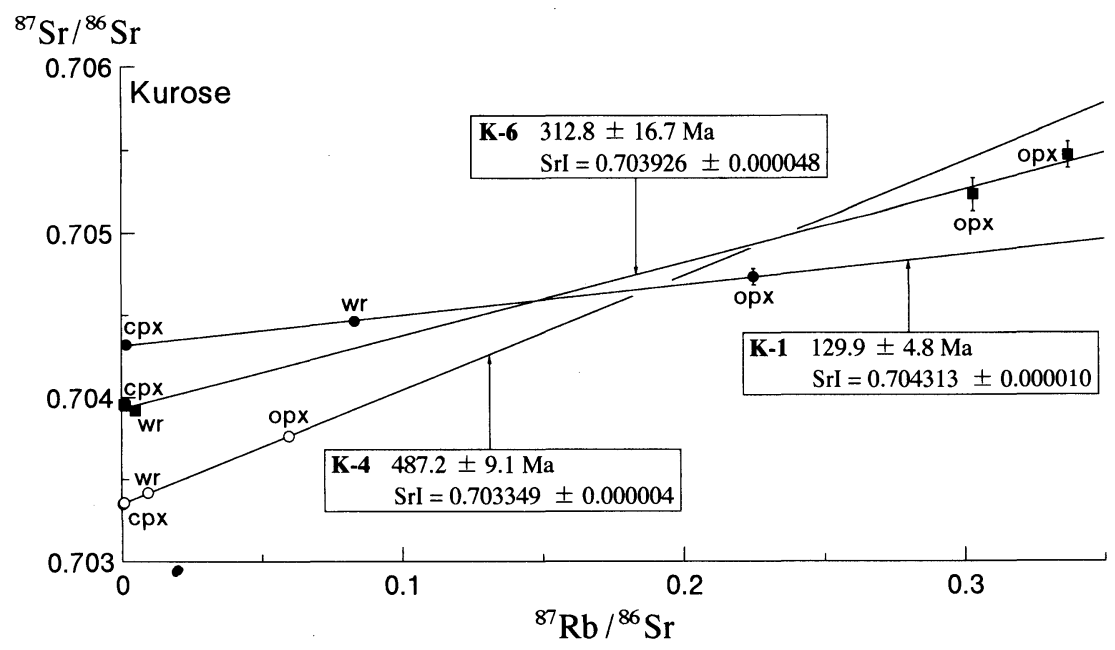

Fig. 9. Rb-Sr isochron diagram for Kurose peridotite xenoliths. Abbreviations as in Fig. 8 .

Table 5. Calculated isochron ages and initial ${ }^{87} \mathrm{Sr} /{ }^{86} \mathrm{Sr}$ ratios of peridotite xenoliths from Ichinomegata and Kurose

\begin{tabular}{|c|c|c|c|}
\hline No. & $\mathrm{Rb}-\mathrm{Sr}$ mineral isochron age & Sr initial ratio & MSWD* \\
\hline \multicolumn{4}{|c|}{ Ichinomegata } \\
\hline $\mathrm{N}-8$ & $233.8 \pm 8.4 \mathrm{Ma}$ & $0.703334 \pm 13$ & 0.01 \\
\hline $370-1$ & $208.9 \pm 80.1 \mathrm{Ma}$ & $0.703162 \pm 211$ & 0.99 \\
\hline 961 & $310.8 \pm 23.3 \mathrm{Ma}$ & $0.703437 \pm 80$ & 0.33 \\
\hline 962 & $252.9 \pm 19.8 \mathrm{Ma}$ & $0.703292 \pm 131$ & 1.74 \\
\hline \multicolumn{4}{|c|}{ Kurose } \\
\hline $\mathrm{K}-1$ & $129.9 \pm 4.8 \mathrm{Ma}$ & $0.704313 \pm 10$ & 0.00 \\
\hline $\mathrm{K}-4$ & $487.2 \pm 9.1 \mathrm{Ma}$ & $0.703349 \pm 4$ & 0.00 \\
\hline $\mathrm{K}-6$ & $312.8 \pm 16.7 \mathrm{Ma}$ & $0.703926 \pm 48$ & 0.16 \\
\hline
\end{tabular}

*, mean squared weighted deviates.

物と母岩の間に混合線が描かれない。

Sneeringer et al. (1984) は単斜輝石（粒子半径 0.2 $\mathrm{cm})$ の Sr の拡散について検討し, 冷却速度と閉鎖温度 の関係を明らかにした。それによると, Stillwater 岩体 のようにマグマが急速に冷却する場合は $10^{4} \sim 10^{5 \circ} \mathrm{C} /$ $\mathrm{Ma}$ 程度の冷却速度が推定され，対応する閉鎖温度は $1050 \sim 1150^{\circ} \mathrm{C}$ になる。いっぽう地温勾配（～200 km） が $1^{\circ} \mathrm{C} / \mathrm{km}$ の地域を $1 \mathrm{~cm} / \mathrm{y}$ の速度で上昇するマント ルダイアピルのように冷却速度が $10^{\circ} \mathrm{C} / \mathrm{Ma}$ であれば 閉鎖温度は $856^{\circ} \mathrm{C}$ である。一の目潟と黒瀬のリソス フェアマントルが受けたマントルイベントの後の冷却 速度は不明なので, 本研究の単斜輝石についての Sr の閉鎖温度も特定できない。しかし彼らは，大陸下の リソスフェアマントルのような低温の条件下 $\left(1000^{\circ} \mathrm{C}\right.$ 以下)では鉱物は $\mathrm{Sr}$ 同位体非平衡にあり，かつての同 位体的平衡化イベントを記録していると考えた。また
Hofmann and Hart (1978) と Zindler and Hart （1986）は，マントル中に流体が存在しない限り，Rb$\mathrm{Sr}$ 系における鉱物間の同位体的非平衡は 10 億年以上 に渡って維持されると述べた。以上のことから，一の 目潟と黒瀬のカンラン岩のアイソクロン年代は, 捕獲 岩がリソスフェアマントルに存在していた時に部分溶 融液や交代流体と最後に共存した時期を示すと考えら れる。

\section{2. 捕獲岩の由来深度の比較}

一の目潟のカンラン岩の平衡温度は, Wells (1977) の輝石温度計によれば 870 $970^{\circ} \mathrm{C}$ となる（Table 1)。 既存の輝石の分析值 (Takahashi, 1980 ; 阿部ら, 1992) から計算した温度 $\left(730 \sim 960^{\circ} \mathrm{C}\right)$ を加えた一の目潟の カンラン岩の平衡温度の範囲は約 $240^{\circ} \mathrm{C}$ になる。いっ 浔う黒瀬のカンラン岩の平衡温度は $900 \sim 1000^{\circ} \mathrm{C}$ の狭 い範囲を示す。このことは Arai and Hirai (1983) の 結果とも一致する。

一の目潟と黒瀬のカンラン岩にみられる平衡温度の 範囲の違いは, 由来深度の範囲に対応する可能性があ る。両地域下の温度・圧力条件が厳密に同じであるこ とはないとしても, 仮に捕獲岩の由来場所の地下増温 率がそれほど変わらないとすると，一の目潟のカンラ ン岩のほうが様々な深度に由来したと考えられる。

\section{3. 一の目潟のリソスフェアマントルの多様性が生 じた時期と炎の要因}

一の目潟のカンラン岩が岩石学的・地球化学的に多 様であることは, 平衡温度の変化幅から示唆されるよ うに，カンラン岩の由来深度の範囲が広いことと関係 
している可能性がある。すなわち,マグマによって様久 な深度からまんべんなく捕獲されてきたため, リソス フェアマントル物質の岩石学的・地球化学的な不均質 性が強調されていると思われる。

鉱物組成と全岩の主成分および M HREE 濃度の 多様性は部分溶融の程度に起因し, それ以外のインコ ンパチブル元素濃度の多様性は交代作用に起因すると 考えた場合，両者が同時に複合的に起こったのか，そ れとも部分溶融による局所的な組成改変の後に, 交代 作用に伴う微量元素のオーバープリントが起こったの かは不明である。Sr をはじめとする単斜輝石の微量成 分の特徵にクリプティックな交代作用が認められる (Abe et al., 1998) とすれば, 本研究の鉱物アイソク ロン年代は，このような交代作用の時期を記録してい る可能性がある。ただし,ドイツのアイフェル(Stosch and Seck, 1980) やモンゴル (Ionov et al., 1994) に 産する捕獲岩の研究では, 部分溶融と交代作用が複合 的に起こったと考えられている。もし同様のプロセス が一の目潟のリソスフェアマントルでも起こったとす れば，アイソクロン年代は部分溶融の時期を示してい ることになる。

上に述べた多様性にもかかわらず，単斜輝石あるい は全岩の $\mathrm{Sr}$ 同位体比測定值 (現在値) が極めて一定で あることは注目される(Fig. 10)。このことは一の目潟 のリソスフェアマントルが様々な深度において, 同位 体的に均質である可能性を示唆している。ただし, Fig. 10 には一の目潟のカンラン岩の既存の分析值のうち 小数点以下 6 桁まで報告されているものを用いたの で, Zashu et al. (1980) と Porcelli et al. (1992) の 分析值は採用していない。また，図に用いた同位体比 の大部分は単斜輝石の測定值であるが，一の目潟と隠 岐島後の試料のうち全岩の測定値しか得られていない 場合は，それも加えた。全岩に含まれる Sr のほとんど は単斜輝石に分配されているので, 全岩と単斜輝石の $\mathrm{Sr}$ 同位体比は類似し, 両者の差はヒストグラムの階級 幅よりも小さい (Table 4)。

試料の $\mathrm{Sr}$ 同位体比初生值が比較的一定であること は，拉よそ $250 \mathrm{Ma}$ 前に起こった同位体的なりセット 以前の特徴を反映している可能性もあるが，もし以前 の $\mathrm{Sr}$ 同位体比が試料ごとに異なっていたとすれば, 流体を介して $\mathrm{Sr}$ 同位体比の平衡化が十分に行われた ことを示唆する。ただし，カンラン岩の岩石学的・地 球化学的な多様性からみて, このときあるいはそれ以 前に起きたリソスフェアマントルの部分溶融の程度は 場所によって異なっていただろう。

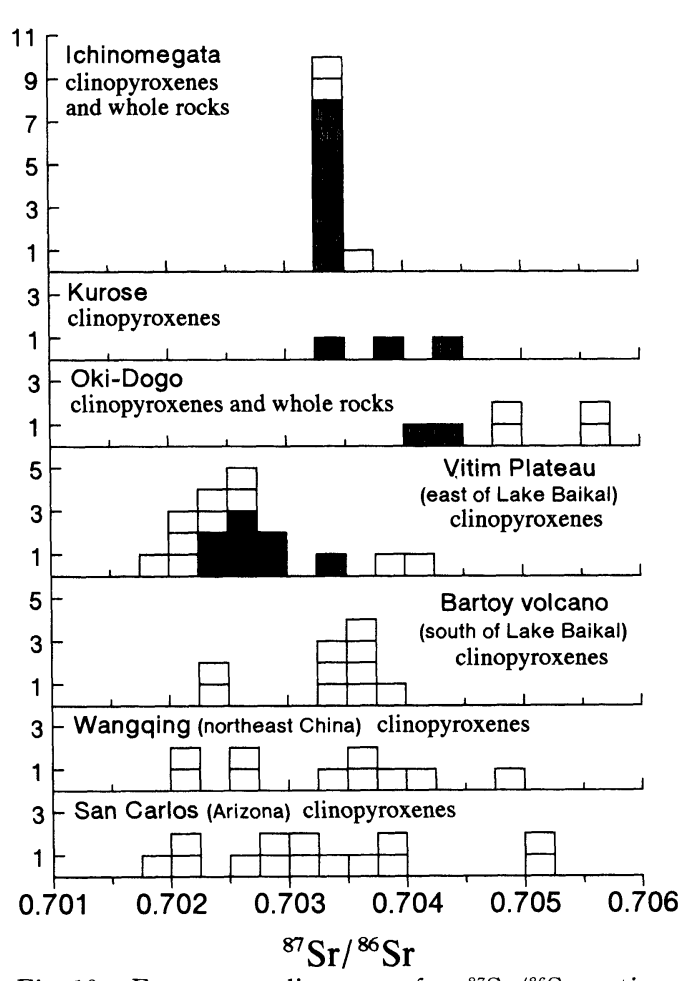

Fig. 10. Frequency diagrams for ${ }^{87} \mathrm{Sr} /{ }^{86} \mathrm{Sr}$ ratios (present-day) of clinopyroxenes of peridotite xenoliths including seven whole rock data.

Data sources: Ichinomegata (Nohda and Wasserburg, 1986; Menzies and Hawkesworth, 1987), Oki-Dogo (Kagami et al., 1986), Vitim (Ionov and Jagoutz, 1989), Bartoy (Ionov et al., 1992), Wangqing (Xu et al., 1998), San Carlos (Galer and O'Nions, 1989). Shaded squares (clinopyroxenes) are from this study (Table 4), Abe (1998) and our unpublished data. Data of N-8 and 962 (Ichinomegata) are represented by their mean value (cpx-1 and $c p x-2$ in Table 4)

カンラン岩捕獲岩に記録されているアイソクロン年 代は, 由来場所の直上で起こった地殼形成の作用に関 連するといわれている(例えば Stosch et al., 1986； Kovalenko et al., 1991)。しかし, 一の目潟のカンラ ン岩が示すアイソクロン年代に対応する地質学的事件 を見出すことは難しい。一の目潟ではアイソクロン年 代に対応する岩石が地表に露出していないので, 下部 地凯起源の捕獲岩の年代についても検討する必要があ る。このほかアイソクロン年代よりは古いが, 東北日 本の南部北上帯における石炭紀の島弧火成作用(永広, 
1995）にも注目する必要があるかもしれない。アセノ スフェアはある一定の冷却時間を経てリソスフェア化 し(河野，1990)，同位体的な閉鎖温度に達すると思わ れるからである。

以上に加え, 一の目潟のカンラン岩中の角閃石の同 位体組成についても検討する必要がある。前述のよう に Abe et al. (1998) は, 単斜輝石の微量成分の特徵 は交代作用によると指摘したが，交代作用の程度と共 存する角閃石のモード量との間に相関があるようには みえない。したがって，一の目潟のカンラン岩中に角 閃石を形成したモーダル交代作用（Harte，1987）は, 単斜輝石に認められる交代作用とは別に起こった可能 性がある。というのは, 以下の例があるからである。バ イカルリフト帯のヴィティムに産するカンラン岩捕獲 岩は, 約 $600 \mathrm{Ma}$ の $\mathrm{Rb}-\mathrm{Sr}$ 鉱物 (カンラン石, 輝石) ア イソクロン年代を示す。しかし同じ試料中の金雲母脈 はこのアイソクロンから外れ，13〜32 Ma に形成され たと考えられている（阿部・山元，1998）。

4. 黒瀬のリソスフェアマントルの多様性が生じた 時期と享要因

黒瀬のカンラン岩の岩石学的・地球化学的な組成変 化は一の目潟よりも小さいが, M HREE を除く微量 成分は変化が大きく，それらのパターンも不規則であ る (Figs. 5, 6)。また試料番号 $\mathrm{K}-4$ と K-6 は V 字型の REE パターンを示す。このことから, 黒瀬のリソス フェアマントルにおいても交代作用のあったことが示 唆される。このことは, 黒瀬のカンラン岩がポーフィ ロクラスティック組織を示すことと調和的である。一 般に変形組織 (ポーフィロクラスティック, 等粒状) を 有するカンラン岩は, プロトグラニュラー組織のもの に比べてインコンパチブル元素に富む傾向にある（例 えば Downes, 1990 ; Downes et al., 1992 ; Xu et al., 1998)。また岩石記載で述べたように，スピネルと斜方 輝石の粒界に形成された主に微細なカンラン石からな る鉱物集合体の存在も注目される。

黒瀬のカンラン岩のアイソクロン年代や単斜輝石の $\mathrm{Sr}$ 同位体比は, 一の目潟のものに比べて変化が大きい (Figs. 9, 10)。また年代と Sr 同位体比初生值の関係は 特定のマントル進化線を描かない。したがって, 黒瀬 のカンラン岩にみられる著しい年代の違いを，均質な マントル物質の閉鎖系における単純な部分溶融で説明 することはできない。約 5 億年, 3 億年および 1 億年前 という離れた時期に起こった同位体的なリセットは, それぞれ同位体的に起源の異なる交代作用あるいはそ れに伴う部分溶融によると考えられる。
黒瀬のカンラン岩の平衡温度は, 一の目潟の場合よ りも変化が小さいので, 由来深度もそれほど変わらな い可能性がある。それにもかかわらず，カンラン岩の $\mathrm{Sr}$ 同位体比初生値は著しく異なる。したがって, 同位 体的なりセットを引き起こした作用は一の目潟の場合 よりも局所的であった可能性がある。

交代作用の起こった時期について, Abe et al. (1998) は日本列島下の広域にわたる定常的なマントル 交代作用を主張している。しかし連続的な交代作用は 考えにくく,一の目潟ではおよそ $250 \mathrm{Ma}$ 前, 黒瀬では およそ 130〜 490 Ma 前の間にマントルイベントが断 続的に起こったと考えられる。

黒瀬の試料はわずか 3 個ではあるが，以下のような 傾向がある。K-4, K-6, K-1 の順に, 平衡温度および $\mathrm{La} / \mathrm{Yb}$ 比が低く, 単斜輝石の $\mathrm{Sr}$ 同位体比が高く,さら にアイソクロン年代が若くなる。最近, 加々美ら (1999) は黒瀬の下部地壳捕獲岩について, 西南日本の花こう 岩の年代とほぼ一致する $\mathrm{Sm}-\mathrm{Nd}$ 鉱物アイソクロン年

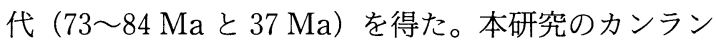
岩の年代はこれらと一致しないが, 平衡温度が低いほ ど年代が若いという傾向を浅部へ外挿できるとすれ ば, 下部地殼物質のほかに, 花こう岩マグマの形成に 関与するもう一つの成分として, $80 \mathrm{Ma}$ 前後を示す最 上部マントル物質がみつかる可能性もある。このほか, 北部九州の花こう岩の活動はおよそ $120 \mathrm{Ma}$ 前に始 まったと考えられており（大和田ら，1997），K-1がこ れと似た年代を示すことも注目される。

\section{5. 一の目潟と黒瀬のリソスフェアマントルの同位 体的特徴}

一の目潟のカンラン岩試料 961 と 962 の単斜輝石 は, Nd-Sr 同位体図で MORB 領域 (Zindler and Hart, 1986)よりも ${ }^{143} \mathrm{Nd} /{ }^{144} \mathrm{Nd}$ 比が低く, Low Nd (LoNd) array（Hart et al., 1986） に近い位置にプロットされ る (Fig. 11)。

日本海を含む東アジア地域のマントルの同位体的特 徵に関して,様々なマントル成分が提案されている。そ のうちリソスフェアマントルについては, Enriched Mantle (EM ; Zindler and Hart, 1986) 成分の特徵を 示すことが指摘されている (Tatsumoto and $\mathrm{Na}$ kamura, 1991; Tatsumoto et al., 1992; Pouclet et al., 1995)。これに対して, 一の目潟のカンラン岩はや や High $\mu$ (HIMU ; Zindler and Hart, 1986) 的であ る (Fig. 11)。一の目潟以外にも，中国東北部の Hannuoba のカンラン岩捕獲岩の同位体的特徵から LoNd 様成分が指摘されている (Song and Frey, 1989)。ま 


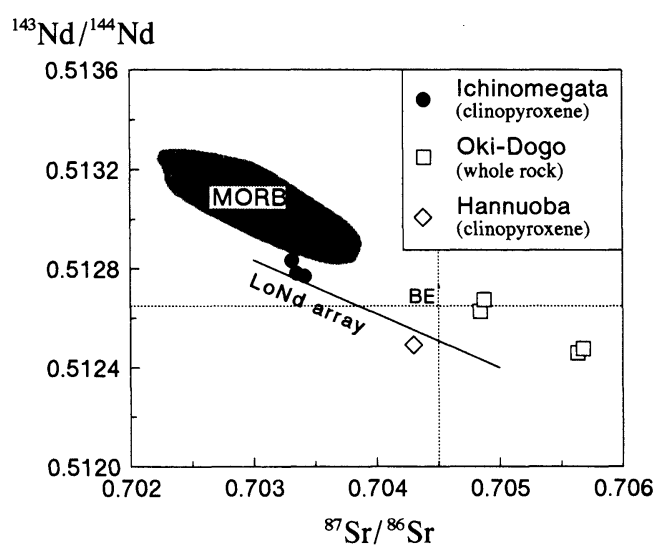

Fig. 11. Present-day $\mathrm{Nd}$ and $\mathrm{Sr}$ isotope variation diagram of clinopyroxenes including whole rock data of peridotite xenoliths from Ichinomegata, Oki-Dogo and Hannuoba, east China. Data sources: clinopyroxenes of Ichinomegata, this study; whole rocks of Oki-Dogo, Kagami et al. (1986) ; clinopyroxenes of Hannuoba, Song and Frey (1989). MORB field after Zindler and Hart (1986). Present-day bulk earth (BE) after Faure (1986). LoNd array as solid line after Hart et al. (1986).

た，中国東部の新生代玄武岩の同位体的特徵に HIMU 成分が関与しているらしい (Zartman et al., 1991)。 HIMU 成分についてはアセノスフェア起源とする考 えがある(Okamura et al., 1998)。しかし, リソスフェ アマントルにおいても，EM 成分に相補的なものとし て (Dickin, 1995), 一の目潟や Hannuoba のカンラン 岩捕獲岩から示唆されるように, HIMU 的なマントル 成分が存在する可能性がある。

黒瀬のカンラン岩中の単斜輝石の Sr 同位体比はす べて Uniform Reservoir (DePaolo and Wasserburg, 1979）より低いが, 西南日本のほかの産地のカンラン 岩捕獲岩の単斜輝石は様々な $\mathrm{Sr}$ 同位体比を示す (0.7036〜 57, Fig. 12)。西南日本のリソスフェアマン トルについては, マントルメガリスに押し上げられた 始源的マントルの存在 (Kagami et al., 1986), ある いは Depleted MORB マントル (Zindler and Hart, 1986）の存在（角縁ら，1995）が提案されている。し かし Fig. 12 に示すように, 西南日本のリソスフェア マントルは同位体的に幅が広く, 複数のマントル成分 からなる可能性がある。

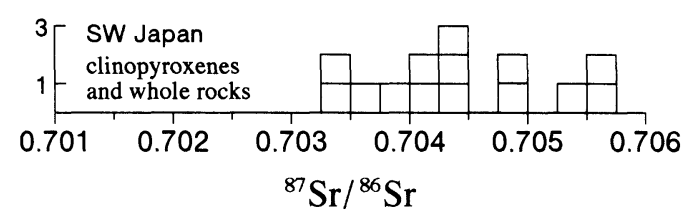

Fig. 12. Frequency diagram for ${ }^{87} \mathrm{Sr} /{ }^{86} \mathrm{Sr}$ ratios (present-day) of clinopyroxenes and four whole rocks of peridotite xenoliths from southwest Japan (On-yama, Aratoyama, Noyama-dake, Kawasimo, Oki-Dogo, Kurose, Fukue-jima). Data sources: this study (Table 4), Kagami et al. (1986), Abe (1998) and our unpublished data.

謝 辞 秋田大学の丸山孝彦氏には日常的に御指 導と激励をいただいている。北海道大学の新井田清信 氏には同大学の X 線マイクロアナライザーおよび質 量分析装置による測定に御援助いただいた。秋田県資 源技術開発機構（財）の岸勉氏には同機構の X 線マイ クロアナライザーによる測定にお世話いただいた。秋 田大学の北逸郎, 水田敏夫, 浅川敬公および安井光大 氏には ICP 質量分析装置と蛍光 X 線装置による分析 に御指導・御援助をいただいた。岡山大学の岡野修氏 には同位体分析について御助言をいただいた。広島大 学の早坂康隆氏には文献を紹介していただいた。秋田 大学の B. ジャヤデワン氏には英文要旨を書くにあた り御指導をいただいた。また, 匿名の査読者および金 沢大学の荒井章司, 石渡明の両氏からは有益な御助言 をいただいた。以上の方々にお礼申し上げる。

\section{引用文献}

阿部洋美 (1998), 西南日本のマントルゼノリスとその 玄武岩質母岩の $\mathrm{Sr}-\mathrm{Nd}$ 同位体的特徵. pp. 113, 秋 田大卒業論文。

阿部なつ江, 荒井章司, 佐伯泰広 (1992), 目潟火山の かんらん岩捕獲岩に見られる島弧マントルの加水 作用. 岩鉱, 87, 305-317.

Abe, N., Arai, S. and Yurimoto, H. (1998), Geochemical characteristics of the uppermost mantle beneath the Japan island arcs: implications for upper mantle evolution. Phys. Earth Planet. Int., 107, 233-248.

阿部志保, 山元正継 (1998), バイカル湖東方ヴィティ ム玄武岩に含まれるザクロ石レルゾライトの $\mathrm{Rb}-\mathrm{Sr}$ 鉱物アイソクロン年代. 日本地質学会第 105 年学術大会講演要旨, 194.

Aoki, K. and Shiba, I. (1973), Pyroxenes from lherzolite inclusions of Itinome-gata, Japan. Lithos, 6, 41-51.

Arai, S. and Hirai, H. (1983), Petrographical notes 
on deep-seated and related rocks (1) Mantle peridotites from Kurose and Noyamadake alkali basalts, southwestern Japan. Ann. Rep., Inst. Geosci., Univ. Tsukuba, 9, 65-67.

Burwell, A.D.M. (1975), Rb-Sr isotope geochemistry of lherzolites and their constituent minerals from Victoria, Australia. Earth Planet. Sci. Lett., 28, 69-78.

DePaolo, D.J. and Wasserburg, G.J. (1979), Petrogenetic mixing models and $\mathrm{Nd}-\mathrm{Sr}$ isotopic patterns. Geochim. Cocmochim. Acta, 43, 615-627.

Dickin, A.P. (1995), Radiogenic isotope geology, pp. 452, Cambridge University Press.

Downes, H. (1990), Shear zones in the upper mantle-relation between geochemical enrichment and deformation in mantle peridotites. Geology, 18, 374-377.

Downes, H., Embey-Isztin, A. and Thirlwall, M.F. (1992), Petrology and geochemistry of spinel peridotite xenoliths from the western Pannonian Basin (Hungary): evidence for an association between enrichment and texture in the upper mantle. Contrib. Mineral. Petrol., 109, 340-354.

永広昌之 (1995), 東北日本の古い山地, 日本列島のお いたち. pp. 177, 東海大学出版会, 53-63.

Faure, G. (1986), Principles of isotope geology, 2nd edition, pp. 589, John Wiley \& Sons.

Frey, F.A. and Prinz, M. (1978), Ultramafic inclusions from San Carlos, Arizona: petrologic and geochemical data bearing on their petrogenesis. Earth Planet. Sci. Lett., 38, 129176.

Galer, S.J.G. and O'Nions, R.K. (1989), Chemical and isotopic studies of ultramafic inclusions from the San Carlos volcanic field, Arizona : a bearing on their petrogenesis. J. Petrol., 30, 1033-1064.

Günther, M. and Jagoutz, E. (1994), Isotopic disequilibria ( $\mathrm{Sm} / \mathrm{Nd}, \mathrm{Rb} / \mathrm{Sr}$ ) between minerals of coarse grained, low temperature garnet peridotites from Kimberly Floors, southern Africa. Proc. 5th International Kimberlite Conf., 1. pp. 495, Companhia de Pesquisa de Recursos Minerais (CPRM), Rio de Janeiro, Brazil, 354-365.

Hart, S.R. and Zindler, A. (1986), In search of a bulk-earth composition. Chem. Geol., 57, 247267.

Hart, S.R., Gerlach, D.C. and White, W.M. (1986), A possible new $\mathrm{Sr}-\mathrm{Nd}-\mathrm{Pb}$ mantle array and consequences for mantle mixing. Geochim.
Cosmochim. Acta, 50, 1551-1557.

Harte, B. (1987), Metasomatic events recorded in mantle xenoliths: an overview. In Mantle Xenoliths (Nixon, P.H. Ed), pp. 844, John Wiley \& Sons, 625-640.

Hofmann, A.W. (1988), Chemical differentiation of the Earth: the relationship between mantle, continental crust, and oceanic crust. Earth Planet. Sci. Lett., 90, 297-314.

Hofmann, A.W. and Hart, S.R. (1978), An assessment of local and regional isotopic equilibrium in the mantle. Earth Planet. Sci. Lett., 38, 4462.

Ionov, D.A. and Jagoutz, E. (1989), Isotope behavior of strontium and neodymium in minerals of garnet- and spinel- containing peridotite xenoliths of the Vitim Plateau: first data from the USSR on the mantle inclusions. Transactions (Doklady) USSR Acad. Sci. : Earth Sci. Sect., 301, 232-236.

Ionov, D.A., Hofmann, A.W. and Shimizu, N. (1994), Metasomatism-induced melting in mantle xenoliths from Mongolia. J. Petrol., 35, 753-785.

Ionov, D.A., Kramm, U. and Stosch, H.-G. (1992), Evolution of the upper mantle beneath the southern Baikal rift zone: an $\mathrm{Sr}-\mathrm{Nd}$ isotope study of xenoliths from the Bartoy volcanoes. Contrib. Mineral. Petrol., 111, 235-247.

Ionov, D.A., O'Reilly, S.Y. and Ashchepkov, I.V. (1995), Feldspar-bearing lherzolite xenoliths in alkali basalt from Hamar-Daban, southern Baikal region, Russia. Contrib. Mineral. Petrol., 122, 174-190.

Ishibashi, K. (1970), Petrochemical study of basic and ultrabasic inclusions in basaltic rocks from northern Kyushu, Japan. Mem. Fac. Sci., Kyushu Univ., D, Geology, XX, 85-146.

Jagoutz, E., Palme, H., Baddenhaysen, H., Blue, K., Cendales, M., Dreibus, G., Spettel, B., Lorenz, V. and Wänke, H. (1979), The abundances of major, minor and trace elements in the earth's mantle as derived from primitive ultramafic nodules. 10th Proc. Lunar Planet. Sci. Conf., 2031-2050.

Kagami, H., Iwata, M. and Sano, S. (1987), Sr and $\mathrm{Nd}$ isotopic composition and $\mathrm{Rb}, \mathrm{Sr}, \mathrm{Sm}$ and $\mathrm{Nd}$ concentrations of standard samples. Tech. Rep. ISEI., Okayama Univ., Ser. A., 4, 1-16.

Kagami, H., Iwata, M. and Takahashi, E. (1986), Isotopic evidence for primitive mantle beneath the sea of Japan, a young back arc basin. Tech. Rep. ISEI., Okayama Univ., Ser. B., 7, 7- 
13.

加々美寛雄, 岡野 修, 須藤 宏, 本間弘次 (1982), MAT260による $\mathrm{Sr}$ 同位体比測定及び $\mathrm{Rb} ・ \mathrm{Sr}$ 定 量分析. 岡山大温研報, 52, 51-70.

加々美寛雄, 大和田正明, 大石裕之, 岩田昌寿 (1999), 北九州，新生代火山岩に捕獲された苦鉄質グラ ニュライトの $\mathrm{Sr} \cdot \mathrm{Nd}$ 同位体比. 地質学論集（印 刷中).

角縁 進，永尾隆志，加々美寛雄，藤林紀枝（1995）， 西南日本，後期新生代玄武岩類の起源マントルの 特徵. 地質学論集, 44, 321-335.

Katsui, Y., Yamamoto, M., Nemoto, S. and Niida, K. (1979), Genesis of calk-alkalic andesites from Oshima-Oshima and Ichinomegata volcanoes, north Japan. J. Fac. Sci. Hokkaido Univ., IV-19, 157-168.

川野良信（1994），パーソナルコンピュータを用いた $\mathrm{Rb}-\mathrm{Sr}, \mathrm{Sm}-\mathrm{Nd}$ アイソクロン計算プログラム。情 報地質，5，13-19.

河野芳輝 (1990), プレート生長説と日本海の成因. 号 外地球, 3, 80-86.

Kovalenko, V.I., Ionov, D.A., Yarmolyuk, V.V., Jagoutz, E., Lugmair, G.W. and Stosch, H.-G. (1991), Isotope data on the evolution of the mantle and its correlation with the evolution of the crust in some parts of central Asia. Geo chem. Internatl., 28, 82-92.

Kuno, H. and Aoki, K. (1970), Chemistry of ultramafic nodules and their bearing on the origin of basaltic magmas. Phys. Earth. Planet. Interiors, 3, 273-301.

Maalфe, S. and Aoki, K. (1977), The major element composition of the upper mantle estimated from the composition of lherzolites. Contrib. Mineral. Petrol., 63, 161-173.

Masuda, A., Nakamura, N. and Tanaka, T. (1973), Fine structures of mutually normalized rareearth patterns of chondrites. Geochim. Cosmochimi. Acta., 37, 239-248.

McDonough, W.F. (1990), Constrains on the composition of the continental lithospheric mantle. Earth Planet. Sci. Lett., 101, 1-18.

McDonough, W.F., Stosch, H.-G. and Ware, N.G. (1992), Distribution of titanium and the rare earth elements between peridotitic minerals. Contrib. Mineral. Petrol., 110, 321-328.

Menzies, M.A. and Hawkesworth, C.J. (1987), Upper mantle processes and composition. In Mantle Xenoliths (Nixon, P.H. Ed), pp. 844, John Wiley \& Sons, 725-738.

Mercier, J.-C. and Nicolas, A. (1975), Textures and fabrics of upper mantle peridotites as illustrated by xenoliths from basalts. J. Petrol., 16,
454-487.

Nohda, S. and Wasserburg G.J. (1986), Trends of $\mathrm{Sr}$ and $\mathrm{Nd}$ isotopes through time near the Japan Sea in northeastern Japan. Earth Planet. Sci. Lett., 78, 157-167.

Okamura, S., Arculus, R.J., Martynov, Y.A., Kagami, H., Yoshida, T. and Kawano, Y. (1998), Multiple magma source involved in marginal-sea formation: $\mathrm{Pb}, \mathrm{Sr}$, and $\mathrm{Nd}$ isotopic evidence from the Japan Sea region. Geology, 26, 619-622.

大和田正明, 亀井淳志, 山本耕次, 小山内康人, 加久 美寛雄（1997），中北部九州，白亜紀花崗岩類の火 成活動場とその起源. 九州のテクトニクスワーキ ンググループ研究連絡誌, 1, 19-25.

Porcelli, D.R., O’Nions, R.K., Galer, S.J.G., Cohen, A.S. and Mattey, D.P. (1992), Isotopic relationships of volatile and lithophile trace elements in continental ultramafic xenoliths. Contrib. Mineral. Petrol., 110, 528-538.

Pouclet, A., Lee, J-S., Vidal, P., Cousens, B. and Bellon, H. (1995), Cretaceous to Cenozoic volcanism in south Korea and in the sea of Japan : magmatic constrains on the opening of the back-arc basin. In Volcanism Associated with Extension at Consuming Plate Margins (Smellie, J.L. Ed.), Geol. Soc. Spec. Publ., 81, 169-191.

Richardson, S.H., Erlank, A.J. and Hart, S.R. (1985), Kimberlite-borne garnet peridotite xenoliths from old enriched subcontinental lithosphere. Earth Planet. Sci. Lett., 75, 116128

Sakuyama, M. and Koyaguchi, T. (1984), Magma mixing in mantle xenolith-bearing calc-alkalic ejecta, Ichinomegata volcano, northeastern Japan. J. Volcanol. Geotherm. Res., 22, 199224.

Sneeringer, M., Hart, S.R. and Shimizu, N. (1984), Strontium and samarium diffusion in diopside. Geochim. Cosmochim. Acta., 48, 1589-1608.

Song, Y. and Frey, A. (1989), Geochemistry of peridotite xenoliths in basalt from Hannuoba, eastern China : implications for subcontinental mantle heterogeneity. Geochim. Cosmochim. Acta, 53, 97-113.

Steiger, R.H. and Jäger, E. (1977), Subcommision on geochronology: convention on the use of decay constants in geo- $^{-}$and cosmo-chronology. Earth Planet. Sci. Lett., 36, 359-362.

Stosch, H.-G. and Seck, H.A. (1980), Geochemistry and mineralogy of two spinel peridotite suites from Dreiser Weiher, west Germany. Geo 
chim. Cosmochim. Acta, 44, 457-470.

Stosch, H.-G., Lugmair, G.W. and Kovalenko, V.I. (1986), Spinel peridotite xenoliths from the Tariat Depression, Mongolia. II : Geochemistry and $\mathrm{Nd}$ and $\mathrm{Sr}$ isotopic composition and their implications for the evolution of the sub. continental lithosphere. Geochim. Cosmochim. Acta, 50, 2601-2614.

Stueber, A.M. and Ikramuddin, M. (1974), Rubidium, strontium and the isotopic composition of strontium in ultramafic nodule minerals and host basalts. Geochim. Cosmochim. Acta, 38, 207-216.

Takahashi, E. (1980), Thermal history of lherzolite xenoliths-I. petrology of lherzolite xenoliths from the Ichinomegata crater, Oga peninsula, northeast Japan. Geochim. Cosmochim. Acta, 44, 1643-1658.

Tanaka, T. and Aoki, K. (1981), Petrogenic implications of REE and $\mathrm{Ba}$ data on mafic and ultramafic inclusions from Itinome-gata, Japan. J. Geol., 89, 369-390.

Tatsumoto, M. and Nakamura, Y. (1991), Dupal anomaly in the Sea of Japan: $\mathrm{Pb}, \mathrm{Nd}$, and $\mathrm{Sr}$ isotopic variations at the eastern Eurasian continental margin. Geochim. Cosmochim. Acta, 55, 3697-3708.

Tatsumoto, M., Basu, A.R., Wankang, H., Junwen, W. and Guanghong, X. (1992), Sr, Nd, and $\mathrm{Pb}$ isotopes of ultramafic xenoliths in volcanic rocks of eastern China : enriched components EM I and EM II in subcontinental lithosphere. Earth Planet. Sci. Lett., 113, 107-128.

Wänke, H. (1981), Constitutional of terrestrial planets. Phil. Trans. R. Soc. Lond., A-303, 287-302.

Wells, P.R.A. (1977), Pyroxene thermometry in simple and complex systems. Contrib. Min- eral. Petrol., 62, 129-139.

Wright, T.L. and Doherty, P.C. (1970), Liner programming and least squares computer method for solving petrologic mixing problems. Bull. Geol. Soc. Amer., 81, 1995-2008.

Xu, Y., Menzies, M.A., Vroon, P., Mercier, J-C. and Lin, C. (1998), Texture-temperature-geochemistry relationships in the upper mantle as revealed from spinel peridotite xenoliths from Wangqing, NE China. J. Petrol., 39, 469-493.

山元正継, 丸山孝彦 (1996), MAT261による $\mathrm{Sr}, \mathrm{Nd}$ 同位体比測定と $\mathrm{Rb}, \mathrm{Sr}$ の定量. 秋田大地研報告, 61, 17-30.

York, D. (1966), Least-squares fitting of a straight line. Can. J. Phys., 44, 1079-1086.

芳川雅子, 中村栄三 (1994), 幌満かんらん岩体の同位 体地球化学. 日本地質学会第 101 年学術大会講演 要旨, 26.

Yoshikawa, M., Nakamura, E. and Takahashi, N. (1993), Rb-Sr isotope systematics in a phlogopite-bearing spinel lherzolite and its implications for age and origin of metasomatism in the Horoman peridotite complex, Hokkaido, Japan. J. Min. Petr. Econ. Geol., 88, 121-130.

Zartman, R.E., Futa, K. and Peng, Z.C. (1991), A comparison of $\mathrm{Sr}-\mathrm{Nd}-\mathrm{Pb}$ isotopes in young and old continental lithospheric mantle: Patagonia and eastern China. Aust. J. Earth Sci., 38, 545557.

Zashu, S., Kaneoka, I. and Aoki, K. (1980), Sr isotope study of mafic and ultramafic inclusions from Itinome-gata, Japan. Geochem. J., 14, 123-128.

Zindler, A. and Hart, S. (1986), Chemical geodynamics. Ann. Rev. Earth Planet. Sci., 14, 493-571. 